\title{
45. ALTERATION IN IGNEOUS ROCKS AT DEEP SEA DRILLING PROJECT SITES 458 AND 459, MARIANA FORE-ARC REGION: RELATIONSHIP TO BASEMENT STRUCTURE ${ }^{1}$
}

\author{
James H. Natland, Deep Sea Drilling Project, Scripps Institution of Oceanography, La Jolla, California \\ and \\ John J. Mahoney, Graduate Division, Scripps Institution of Oceanography, La Jolla, California
}

\begin{abstract}
Secondary minerals filling veins and vesicles in volcanic basement at Deep Sea Drilling Project Sites 458 and 459 indicate that there were two stages of alteration at each site: an early oxidative, probably hydrothermal, stage and a later, low-temperature, less oxidative stage, probably contemporaneous with faulting in the tectonically active Mariana forearc region. The initial stage is most evident in Hole 459B, where low-Al, high Fe smectites and iron hydroxides formed in vesicles in pillow basalts and low-Al palygorskite formed in fractures. Iron hydroxides and celadonite formed in massive basalts next to quartz-oligoclase micrographic intergrowths. Palygorskite was found in only one sample near the top of basement in Hole 458, but it too is associated with iron hydroxides. Palygorskite has previously been reported only in marine sediments in DSDP and other occurrences. It evidently formed here as a precipitate from fluids in which $\mathrm{Si}, \mathrm{Mg}, \mathrm{Fe}$, and even some $\mathrm{Al}$ were concentrated. Experimental data suggest that the solutions probably had high $p \mathrm{H}$ and somewhat elevated temperatures. The compositions of associated smectites resemble those in hydrothermal sediments and in basalts at the Galapagos mounds geothermal field.

The second stage of alteration was large-scale replacement of basalt by dioctahedral, trioctahedral, or mixed-layer clays and phillipsite along zones of intense fracturing, especially near the bottom of Holes 458 and $459 \mathrm{~B}$. The basalts are commonly slickensided, and there are recemented microfault offsets in overlying sediments. Native copper occurs in one core of Hole 458, but associated smectites are dominantly dioctahedral, unlike Hole 459B, where they are mainly trioctahedral, indicating nonoxidative alteration. The alteration in both holes is more intense than at most DSDP ocean crust sites and may have been augmented by water derived from subducting ocean crust beneath the fore-arc region.
\end{abstract}

\section{INTRODUCTION}

This chapter presents a petrographic, X-ray diffraction, and electron microprobe reconnaisance of alteration minerals in igneous basement recovered at Deep Sea Drilling Project Sites 458 and 459, drilled beneath the fore-arc sediment prism between the Mariana arc and trench (Fig. 1). The study was undertaken because preliminary shipboard lithologic and petrographic examination had revealed the rocks to be moderately to extensively altered. Moreover, in places they are more highly fractured than in typical ocean crust, and alteration is particularly concentrated along these zones.

Petrologically unusual olivine-free boninites were recovered at Site 458, and at both Sites 458 and 459 tholeiitic and quartz-tholeiitic basalts with island arc affinities were cored (Wood et al., this volume). At Site 458 these were beneath 256.5 meters of siliceous nannofossil foraminifer vitric mud, nannofossil chalk, and laminated graded vitric siltstone and sandstone. In Hole 459B the sediment thickness is more than twice this559 meters - and the sediments are considerably less calcareous, with a greater abundance of turbidites, consisting mainly of vitric muds and mudstones, sandy and silty vitric tuffs, and ash. Basement at both sites is extrusive, consisting of alternating flows and pillows with wide ranges in both crystallinity and texture. At both sites it is at least early Oligocene and probably Eocene in age, as old as the oldest exposures in the Mariana arc on Guam and Saipan (Ellis, this volume; Kling, this vol-

\footnotetext{
${ }^{1}$ Initial Reports of the Deep Sea Drilling Project, Volume 60.
}

ume). Basement at Site 458 is part of an elevated structure (either a seamount or, probably, a tectonic block) above flatter and deeper surrounding fore-arc basement. Basement at Site 459 is in block-faulted terrain near the trench/slope break. For additional discussion of these structural relationships, see Hussong and Fryer (this volume) and Mrozowski et al. (this volume).

\section{METHODS}

Small samples of alteration minerals were scraped from fracture coatings or from the linings of larger vugs and cavities. A few wholerock samples were taken as well. Samples were crushed, then mounted in a water paste onto glass slides and allowed to dry. Minerals were identified using standard X-ray diffraction techniques after Warshaw and Roy (1961). Scans at $2 \theta=1 \%$ min. from $0^{\circ}-40^{\circ} 2 \theta$, using $\mathrm{Ni}$ filtered $\mathrm{Cu} \mathrm{K} \alpha$ radiation gave preliminary results. Clay minerals of uncertain composition were then exposed to ethylene glycol vapor for 48 hours and run again from $0^{\circ}-12^{\circ} 2 \theta$. We distinguished dioctahedral clays from trioctahedral clays by measuring the relative position of the 060 reflection (Warshaw and Roy, 1961; Scheidegger and Stakes, 1977). Palygorskite occurred in a number of samples. This occurrence was verified by heating for short periods to over $300^{\circ} \mathrm{C}$ following glycolation and subsequent redetermination of the basal peak. Neither glycolation nor heating shifted the basal peak, demonstrating the existence of palygorskite (Grim, 1968; Warshaw and Roy, 1961). Two samples of suspected palygorskite were scanned at $2 \theta=1 / 2 \% \mathrm{~min}$. with a quartz internal standard and compared with laboratory samples of known palygorskite and related minerals. Results of a typical X-ray diffraction scan for palygorskite are compared with glycolated and heated runs of the same sample, and a standard, in Figure 2.

Further examination of palygorskite was undertaken with a Cambridge S4 Stereoscan scanning electron microscope, and the composition of one sample was determined with a Cameca electron microprobe; both instruments are housed at Scripps Institution of Oceanography. The microprobe analysis was determined on a mounted and polished glass bead prepared by fusing the palygorskite after driving off volatiles at $1000^{\circ} \mathrm{C}$. We also attempted to determine the composition of palygorskite and other minerals by atomic absorption tech- 

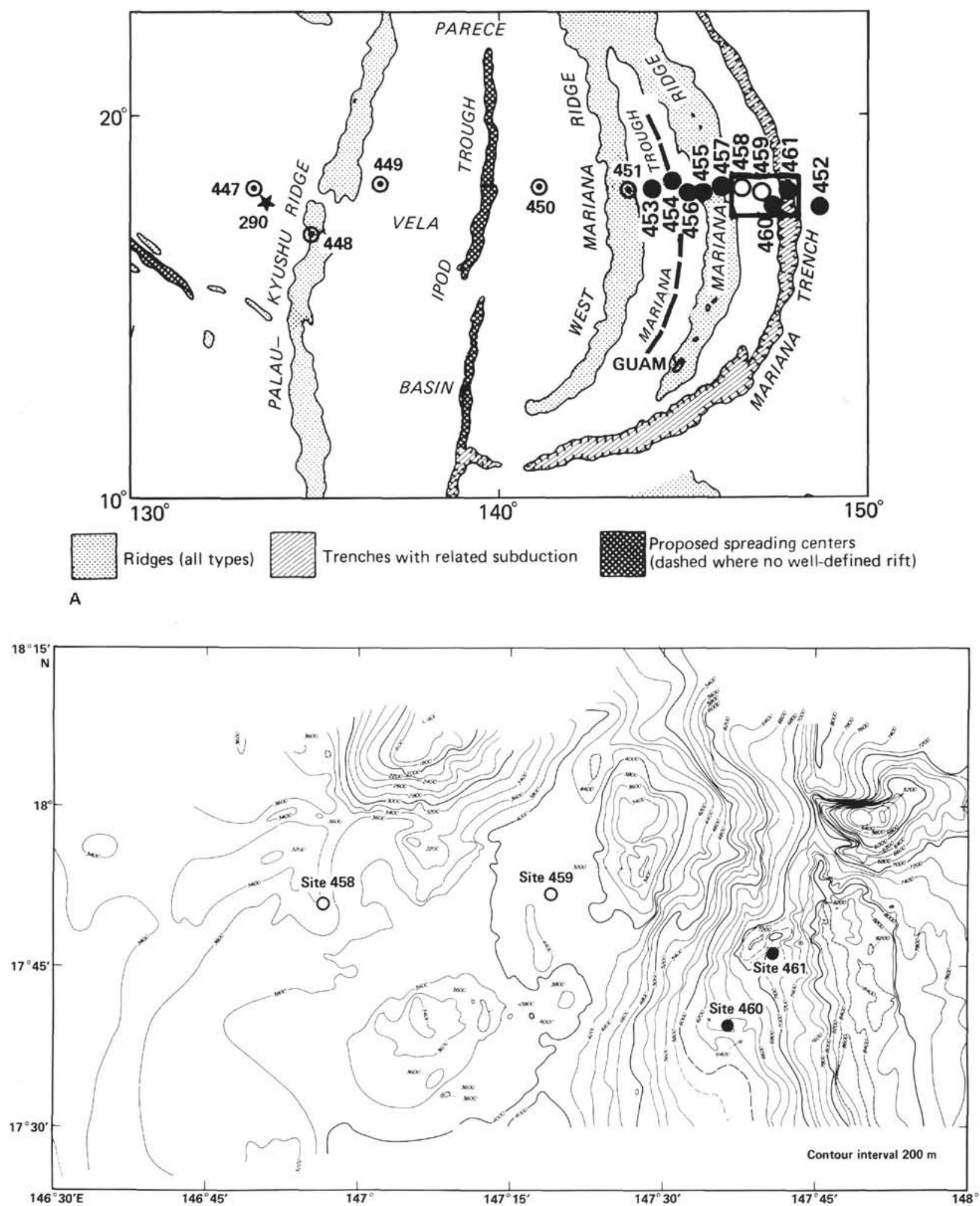

B

Figure 1. A. Location of Sites 458 and 459 in the Mariana fore-arc region (open circles); other Leg 60 sites are closed circles; Leg 59 sites are circled dots; Site 290, Leg 31, is shown by a star. Box encloses area of B, bathymetry of the fore-arc and trench region near Sites 458 and 459 (from Hussong and Fryer, this volume; contour interval is 200 meters). 


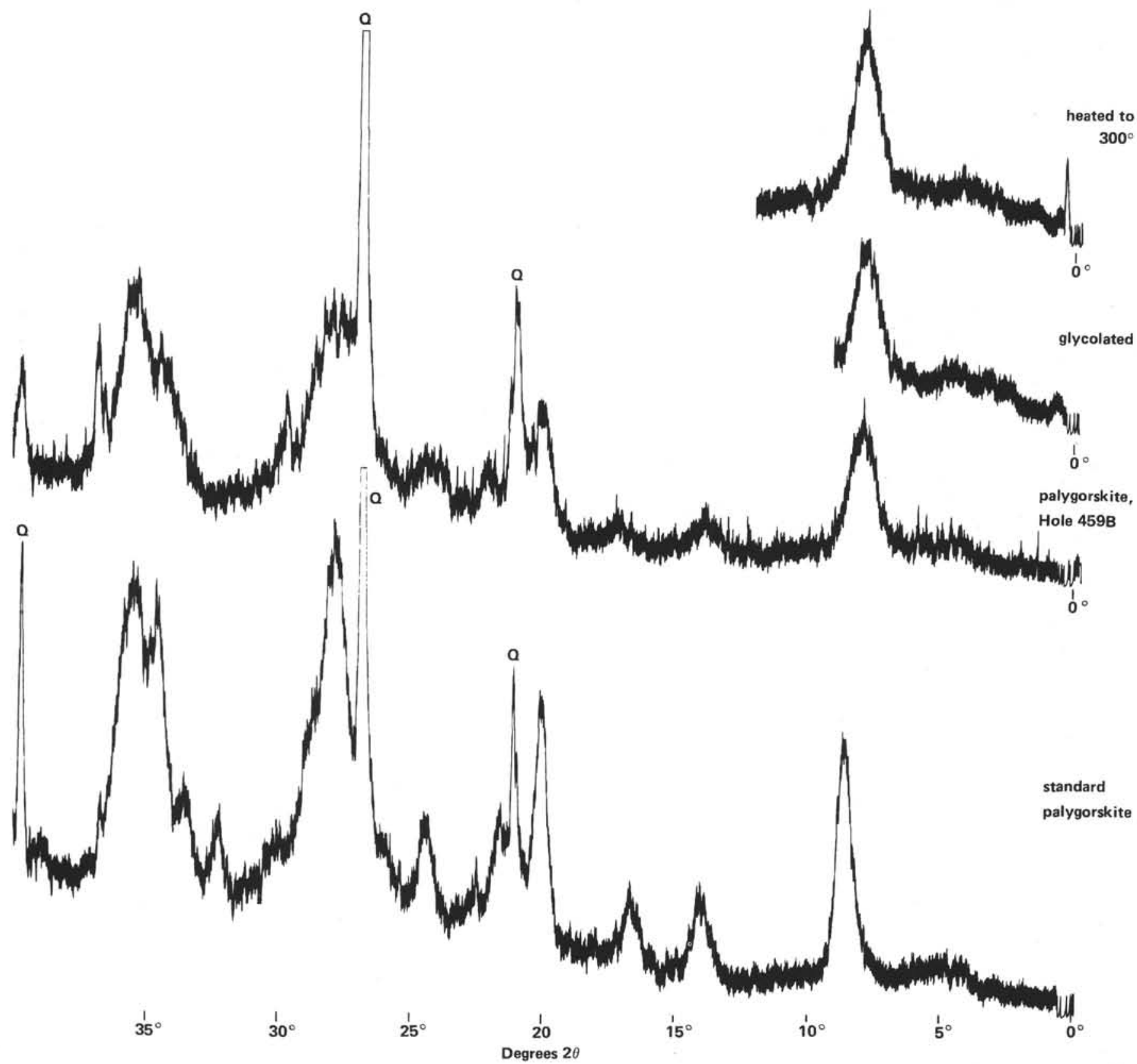

Figure 2. X-ray diffraction patterns for palygorskite Sample 459B-63-1, 52-53 cm (central trace) compared with typical palygorskite (attapulgite from Florida, from Clay Mineral Repository, Dept. of Geology, University of Missouri). The short traces at upper right show the ineffectiveness of either glycolation or heating to $300^{\circ} \mathrm{C}$ in shifting the basal peak of the sample. Peaks labeled Q are those of the quartz internal standard.

niques, but instrument difficulties allowed only qualitative estimates of the abundances of $\mathrm{Mg}$ and $\mathrm{Fe}$. Nevertheless, during preparation of the samples for atomic absorption, we obtained dehydration values by stepwise heating. These values closely match dehydration curves for palygorskite (Fig. 3)

We examined two carbon-coated, polished thin sections by electron microprobe to determine the compositions of minerals associated with palygorskite and to find out if palygorskite formed in vesicles within basalts as well as in veins. There was no palygorskite in the two samples.

\section{X-RAY DIFFRACTION DATA}

Results of the X-ray diffraction analyses for Sites 458 and 459 are presented in Table 1 and in Figures 4 and 5. The figures show summary lithologic sections, indi- cating the occurrences of pillows, thicker flows, and zones of intense fracturing and shear. The chemical stratigraphy of basement is also shown (Type A lavas are boninites [Natland, this volume]; Type B lavas are basalts). The primary magmatic chemistry is discussed further in the relevant site chapters, in Wood et al. (this volume), Meijer et al. (this volume), and in Sharaskin (this volume).

The preliminary reconnaissance for Site 458 lavas revealed primarily the same basic mineral assemblage from top to bottom-phillipsite, largely dioctahedral smectite, and calcite, with only sporadic occurrences of other minerals. Palygorskite was found only at the very top of the basement sequence. In Hole 459B, however, 


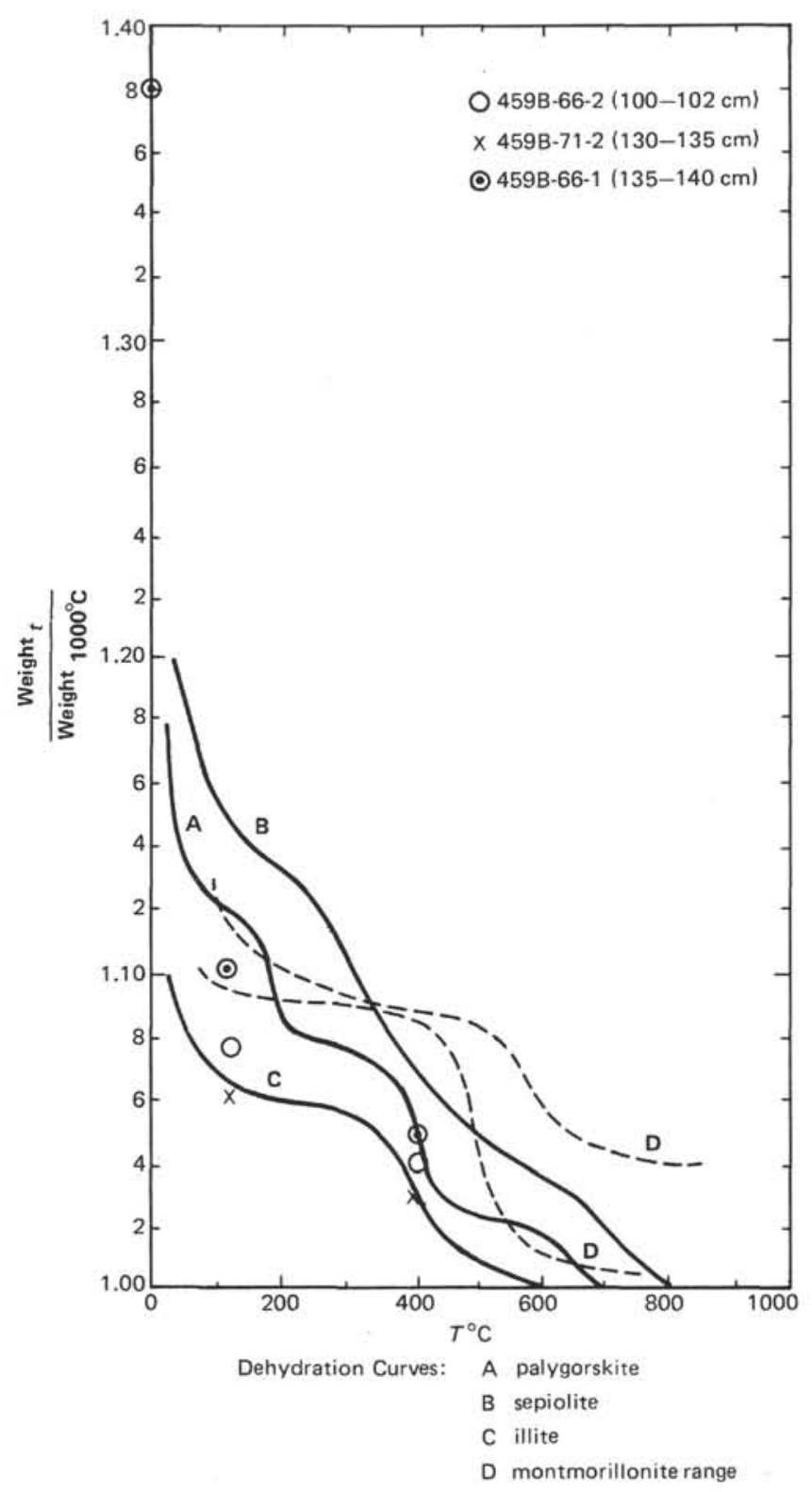

Figure 3. Dehydration data for three Hole 459B palygorskite samples plotted for comparison with dehydration curves for palygorskite, sepiolite, illite, and montmorillonite-group minerals modified from Grim (1968, fig. 9-2). The Hole 459B data were measured as weight loss at $100^{\circ} \mathrm{C}$ and $400^{\circ} \mathrm{C}$ relative to total loss on ignition at $1000^{\circ} \mathrm{C}$ (weight defined as 1.00 after heating to $1000^{\circ} \mathrm{C}$ ). The Hole 459B samples resemble palygorskite and illite in having steady weight loss with increasing temperature, unlike montmorillonitegroup minerals, and have less weight loss overall than sepiolite.

there is greater variation, including the abundant existence of palygorskite. Also, overall, alteration is greater than in Hole 458. Because palygorskite has heretofore been unreported as a secondary mineral in DSDP basalts, Hole 459B was studied in more detail than Hole 458 , primarily to elucidate the manner of its occurrence.

\section{SECONDARY MINERAL ASSEMBLAGES IN HOLE 459B BASALTS}

Based on a combination of optical, X-ray diffraction, and microprobe determinations, there are three basic secondary mineral assemblages in the basalts of
Hole 459B: (1) palygorskite + Fe-hydroxides + yellow or red dioctahedral smectite: (2) palygorskite + celadonite $+\mathrm{Fe}$-hydroxides \pm orange to pale green smectites; and (3) green trioctahedral smectites \pm phillipsite.

Assemblage 1 occurs in the uppermost pillow basalts, and Assemblage 2 in massive basalts of Cores 66-68. The celadonite is a particularly distinctive blue green color, both lining fractures and occurring within the basalts, which consequently have a decided blue green cast. Palygorskite lines fractures, especially toward the top of these massive basalts. Assemblage 3 is particularly abundant in highly fractured basalts both above and below the massive flows. Phillipsite is perhaps more prevalent than indicated by the X-ray diffraction data, since it occurs in several thin sections. Palygorskite does not occur in any of the highly fractured zones, although it is scattered in less altered samples even down to the bottom of the hole.

\section{DESCRIPTION OF SECONDARY MINERAL ASSOCIATIONS IN HOLE 459B}

\section{Palygorskite-Iron Hydroxide-Smectite (Assemblage 1)}

Palygorskite occurs primarily as a pale green or slightly pink vein mineral, coating fracture surfaces on many basalts. Scanning electron micrographs reveal the characteristic fibrous habit of this mineral (Fig. 6). The pattern of growth seems to be crisscrossed mats of crudely oriented fibers. The identity of the smaller, rounded, equant crystals is unknown, but they may be iron hydroxides.

In thin sections from the upper pillow basalts (Fig. 5), inward-growing fibrous crystals line vesicles and are associated with reddish iron hydroxides (dark spots on Fig. 7A and 7B; dark masses to left on Fig. 7C). The fibrous habit of the clay mineral is unmistakable at high magnification (compare D and E, Fig. 7), and our original impression was that it, too, could be palygorskite. Electron microprobe data (Table 2) show this mineral to be $\mathrm{K}$-rich, unlike the vein palygorskite analyzed as a glass bead, and analyses of it produce structural formulae with octahedral layer occupancies close to 4 , strongly indicating that the mineral is a dioctahedral smectite (nontronite) or celadonite. The structural formulae were calculated assuming all iron to be ferric, an assumption that seemed justified by the association of the mineral with iron hydroxides (Fig. 7). This inference was borne out by the coincidence of the 4.0 octahedral site occupancy (Table 2). X-ray diffraction data on samples from this interval, however, revealed no micaceous (celadonite) minerals, indicating that these are smectites. Electron microprobe data of the associated iron hydroxides (Table 2) showed them to be impure-probably mixes of iron hydroxides and smectites. This would explain their rather botryoidal nature and unusual transparency in transmitted light. A microprobe analysis of the yellowish substrate to which the clay minerals are attached (Fig. 7B) proved it to be highly siliceous, (Table 2 , column 8 ), perhaps indicating a combination of opal(?) and clay minerals.

The smectites that line vesicles in most of the basalts in the intervals where palygorskite is abundant are less 
Table 1. Sample descriptions and XRD mineral identifications.

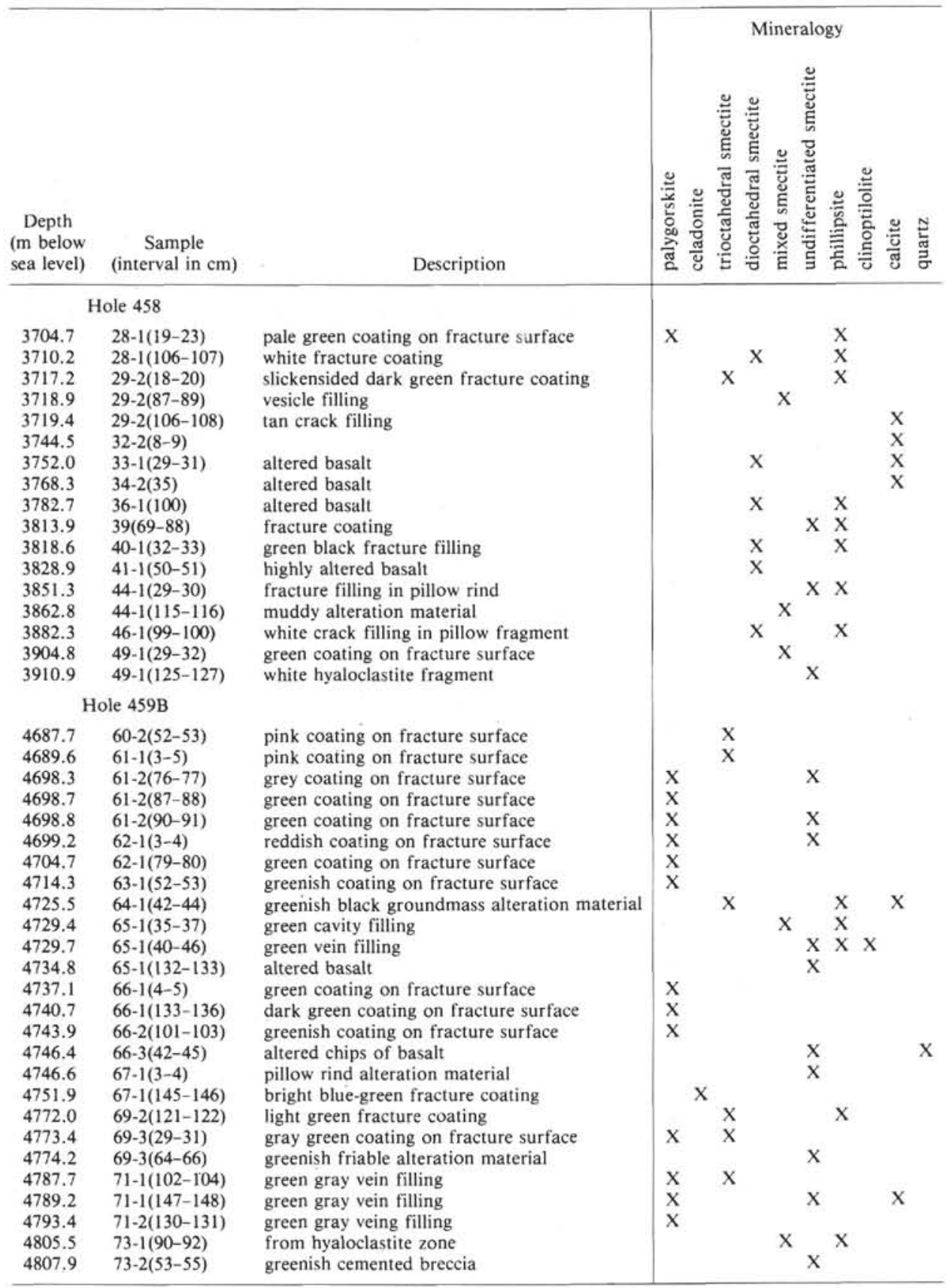

Note: In many samples plagioclase was a prominent constituent. We have ignored it, supposing it to be a contaminant inadvertently scraped from walls of joints, or an unaltered remnant.

a Depths assigned assuming recovery proportional to interval cored.

fibrous. These, too, are associated with iron hydroxides. The example in Figure 8 has a higher birefringence than the clays of Figure 7 and is zoned into two concentric layers. The dark band separating the two layers is iron hydroxide as revealed by reflected light observation (Fig. 8).

\section{Palygorskite-Celadonite-Iron Hydroxide- Smectite (Assemblage 2)}

In this association, palygorskite also occurs only as a vein mineral. Celadonite was identified in one X-ray dif- fraction sample by its $10 \AA$ basal peak and in several thin sections in massive, coarse-grained basalts in Cores 66 and 67 . The bluish tint of the mineral is readily evident in thin sections and is especially vibrant at high magnification with convergent transmitted light. Much of its distinctiveness is lost in black and white photomicrographs (Fig. 9, A and B). Nevertheless, inwardgrowing celadonite crystals clearly are more blade-like than fibrous and are fairly large, allowing them to be distinguished from both types of smectite previously described. In addition they are bluish. 

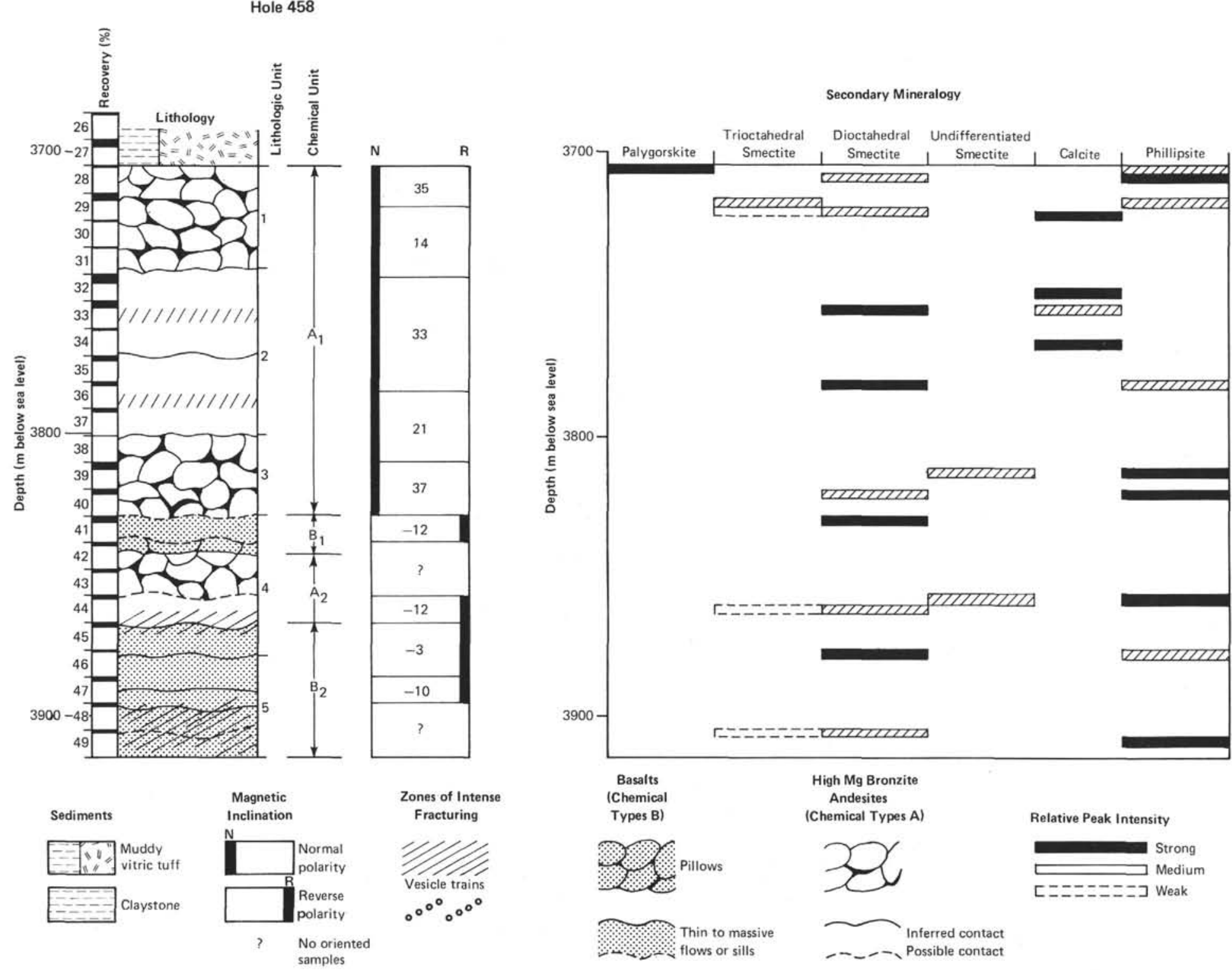

Figure 4. Distribution with depth of Hole 458 secondary minerals in basalts as determined by X-ray diffraction, plotted against summary basement lithology, chemical stratigraphy, and magnetic inclinations. Relative peak intensity assignments are qualitative estimates. 


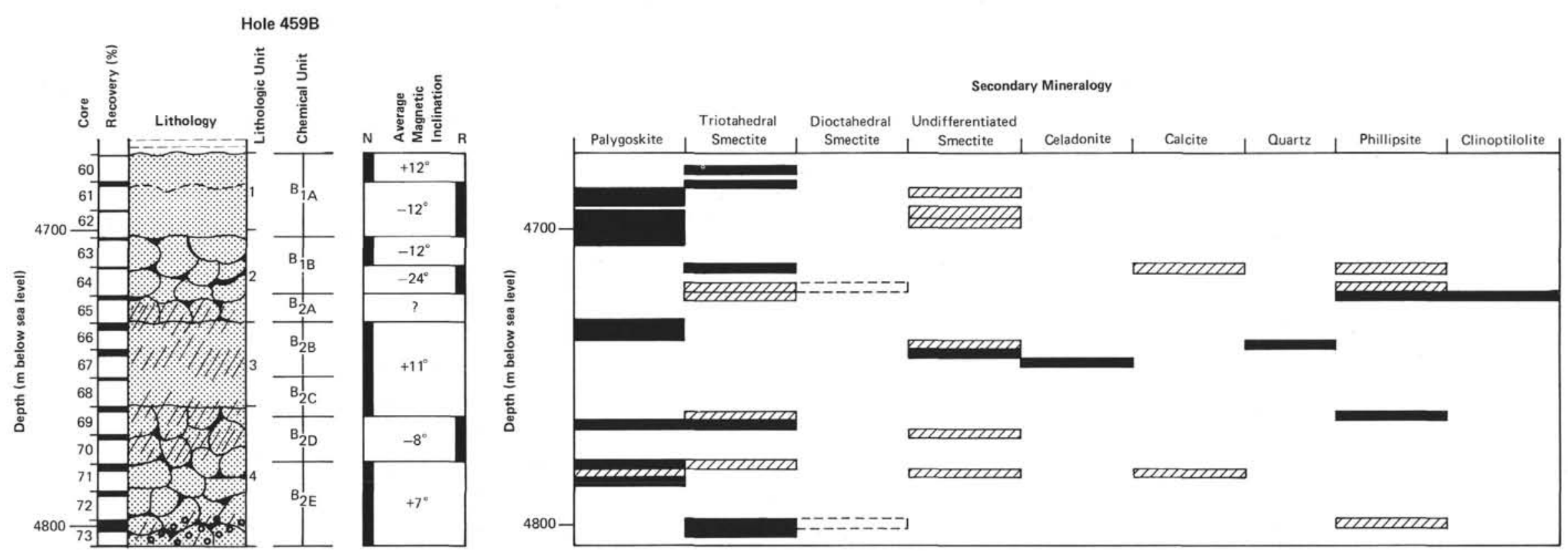

Figure 5. Distribution with depth of Hole 459B secondary minerals in basalts, as determined by X-ray diffraction, plotted against summary basement lithology, chemical stratigraphy, and magnetic inclinations. The distribution of celadonite and phillipsite as determined from thin sections is also indicated by asterisks. Relative peak intensity assignments are qualitative estimates. (Key as on Fig. 4). 

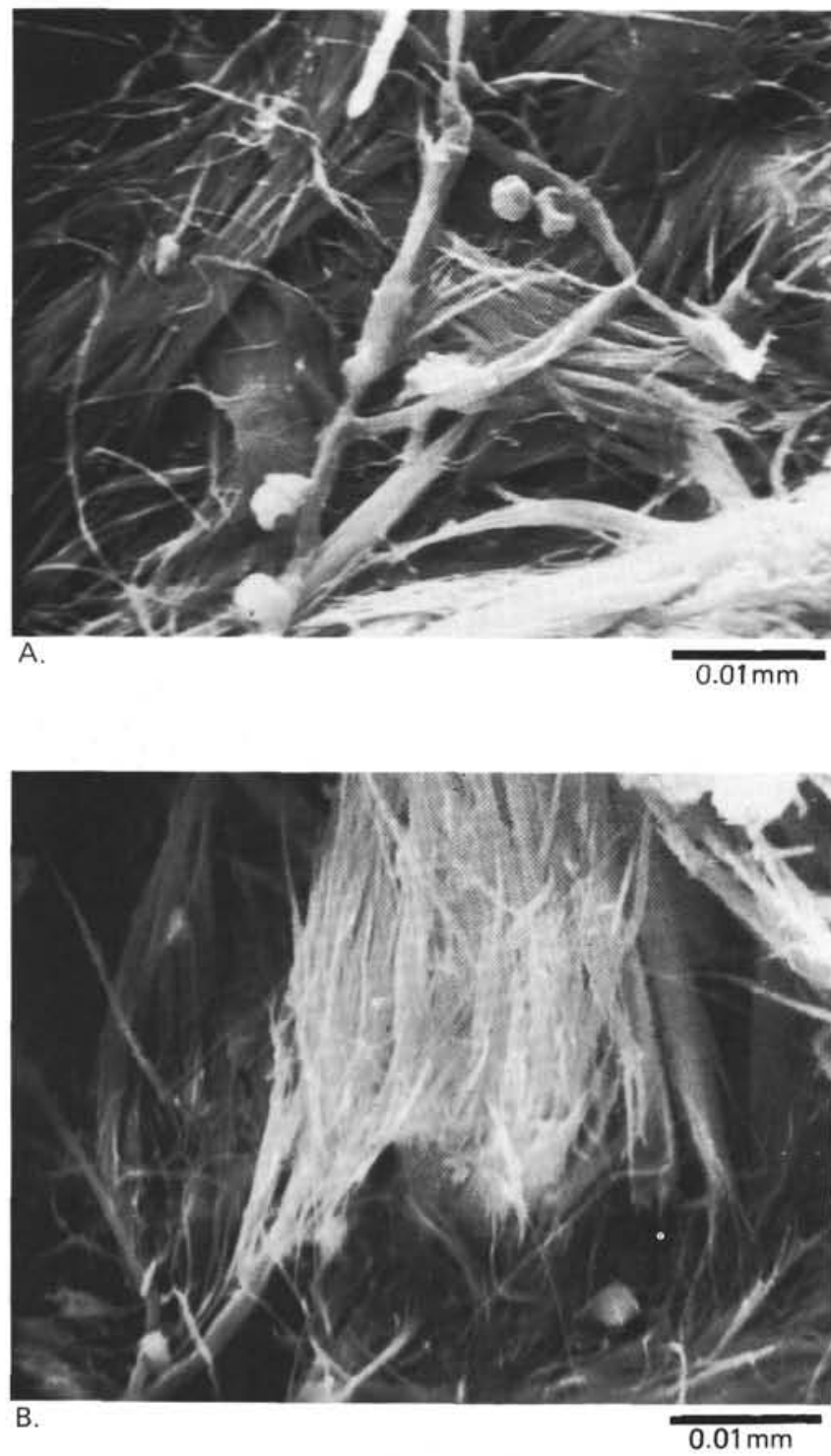

Figure 6. A and B. Scanning electron micrographs showing fibrous habit of vein palygorskite in basalts. Hole 459B, sample from Core $63-1,52-53 \mathrm{~cm}$. (Both exposures were at $1800 \times$.)

The basalts in which celadonite occurs are among the most distinctive in Hole 459B. Not only are they coarse grained, but they evidently experienced extensive in situ magmatic differentiation, leading to the abundant development of quartz-oligoclase micrographic intergrowths (oligoclase determined by electron microprobe). Some of these have a spherulitic texture (Fig. 9C). Blue green celadonite occurs abundantly in or near many of these segregations (Fig. 9D), where it is clear that the outer, probably more alkalic, zones of plagioclase have been replaced by the clay mineral. This is most evident in reflected light (Fig. 9, E and F).

Clinopyroxene has also been replaced by clay minerals in these coarse-grained basalts. Although the replacing minerals vary widely in color, they tend to be either orange or dark green. The orange variety typically replaces portions of the edges of clinopyroxenes (Fig. 10,
$A$ and $B$ ), whereas the dark green variety replaces whole portions of crystals and is vermiform (Fig. 10, C and D).

Both the blue green blade-like clay mineral and the dark green mineral replacing clinopyroxene were analyzed by electron microprobe (Table 2). Both proved to be potassic and moderately aluminous, with those replacing clinopyroxene slightly more iron-rich. Octahedral site occupancy again is very nearly 4 , consistent with celadonite in both cases. The blue green mineral grains proved difficult to analyze, probably because of surface irregularities next to the empty cavities in the basalts, and gave quite low totals.

Titanomagnetites in the massive basalts associated with these celadonites are variably replaced by a secondary phase that is darker gray in reflected light (Fig. 11, $\mathrm{A}-\mathrm{C}$ ). Depending on the overall state of alteration of the rocks, the grains can be merely pitted (Fig. 11A) or almost completely replaced. The alteration corresponds to the low-temperature oxidation Stages 3-5 of Johnson and Hall (1979), with Stage 5 (almost complete replacement of the opaque grains by nonopaque material) predominating (Fig. 11, B and C). Ilmenite exsolution lamellae were not observed; hence high-temperature oxidation (approx. $150^{\circ} \mathrm{C}$ or more) did not occur even locally. An unusual opaque mineral phase, an orange iron hydroxide with moderate reflectivity, occurs mantling the relicts of rare, apparently originally mafic, grains in the quartz-alkali feldspar segregations (Fig. $11, \mathrm{D}$ and $\mathrm{E})$. This association suggests that the original grains may have been fayalitic olivine.

\section{Smectite \pm Phillipsite (Assemblage 3)}

This association occurs in extensively altered basalts, most of them in highly fractured zones in Hole 459B. The smectite in all samples examined by X-ray diffraction is trioctahedral and may be saponite, given the high $\mathrm{Mg}$ abundances determined by our somewhat unsuccessful atomic absorption runs. In fine-grained basalts, alteration is exemplified by large-scale replacement of originally glassy or spherulitic material with various forms of smectite, usually green in color (Fig. 12, A-C). In a somewhat coarser-grained basalt (Fig. 12D), all but the largest plagioclases have been replaced by pale green clays, a feature especially evident in reflected light (Fig. $12 \mathrm{E})$. In some of these samples, there are zones where the clays are more orange, but these are minor and may be relict. The color may also reflect locally variable conditions of oxidation.

Where zeolites occur, however, associated smectites are invariably pale green, with a rather fuzzy outline in vesicles and cavities. These clays mantle radial rosettes of phillipsite in vesicles or intergranular cavities of moderately coarse-grained basalts (Fig. 13, A-D). Besides phillipsite, only one other zeolite, clinoptilolite, was detected in a single X-ray diffraction sample (Table 1), but it was not seen optically.

\section{X-RAY DIFFRACTION CHARACTERISTICS AND COMPOSITION OF PALYGORSKITE}

Palygorskite was identified on the spacing of a fairly broad basal peak (10.8-11.2 $)$ and secondary peaks as 
well as by its behavior upon glycolation (Fig. 2) and dehydration (Fig. 3). Its characteristic fibrous habit was observed with a scanning electron micrograph (Fig. 6). Nonetheless, it differs in one respect from other palygorskites in the literature. Notably, the basal reflection (110) for our material is at about $11.0 \AA$ on the average, whereas it normally occurs at 10.5-10.6 (Table 3; Grim, 1968; Bowles et al., 1971; Weaver and Pollard, 1973). The very similar mineral, sepiolite, exhibits a basal peak at 12.0-12.3 $(\mathrm{Grim}, 1968)$; therefore the Hole 459B material is somewhat intermediate between reported palygorskite and sepiolite with respect to the position of the basal peak. In general, however, $d$ spacings in Table 3 correlate fairly closely with those previously published for palygorskite.

In Figure 14 we have plotted atomic $\mathrm{Al} / \mathrm{Al}+\mathrm{Si}$ versus $\mathrm{Mg} / \mathrm{Mg}+\mathrm{Al}+\mathrm{Fe}$ for our analyzed palygorskite, together with data fields for previously reported montmorillonites and palygorskite (modified from Couture, 1977a) and sepiolite (Grim, 1968). Our palygorskite sample occupies a position on this diagram at the low $\mathrm{Al}$ end of the palygorskite field, near the field for sepiolites, which generally have very low $\mathrm{Al}$. We also attempted to verify the low $\mathrm{Al}$ of our analyzed composition by comparing the $d(200)$ spacing and computed atomic $\mathrm{Al} / \mathrm{Al}+\mathrm{Mg}+\mathrm{Fe}$ for the analysis. Couture (1977a) found these to have a linear correlation, based on a wide selection of samples with $\mathrm{Al}_{2} \mathrm{O}_{3}$ from 6.82$15.44 \%$, taken from Grim (1968). Our palygorskite falls off this trend on the low $\mathrm{Al}$ side. This may in part be because of the poorly defined nature of the 200 peak for most of our samples, but it may also be because our mineral structurally is more like sepiolite, which also falls on the low $\mathrm{Al}$ side of the trend found by Couture. Another explanation for the unusual $d$ spacings may be that our palygorskite is quite high in iron. Assuming all iron to be ferric, a total octahedral site occupancy of precisely 4.0 is obtained in the structural formula (Table 2 ), but this includes 1.16 cations of $\mathrm{Fe}^{3+}$ (compared with $0.02-0.16$ in formulae of typical palygorskites calculated by Couture, 1977a). There is also a deficiency of $\mathrm{Si}$ leading to a large tetrahedral charge of -0.47 . Ca in our analysis is also unusually high, suggesting that it may be somewhat contaminated with plagioclase accidentally scraped from the rock (but no contamination was evident in the X-ray diffractogram obtained on the analyzed specimen). If such contamination has occurred, $\mathrm{Al}$ would also be too high.

\section{Origin of Clay Minerals in Hole 459B Basalts}

The occurrence of palygorskite among a diverse assemblage of smectites, zeolites, celadonite, and iron hydroxides in the basalts of Hole 459B entails conditions of alteration atypical of normal ocean crust. The two features of the alteration most resembling normal ocean crust are the occurrence of trioctahedral magnesian smectite (saponite) and celadonite. The occurrence of saponite with phillipsite is common in younger ocean crust where the clay mineral, at least, is the product of low-temperature, nonoxidative alteration. This is indicated partly because of the low ferric/ferrous ratio of the clay (manifested in the trioctahedral structure) and of the altered rocks in which it resides (e.g., Bass, 1976; Andrews, 1977; Andrews et al., 1977; Scheidegger and Stakes, 1977; Robinson et al., 1977). The importance of saponite and other magnesian clay minerals in basalts as a sink for seawater magnesium has been stressed by Drever (1974), Perry et al. (1976), Lawrence et al. (1975), and Humphris and Thompson (1978).

The occurrence of celadonite in 108 m.y. old ocean crust together with saponite at DSDP Sites 417 and 418 is thought by several workers to be a manifestation of crustal aging. At those sites, these minerals are associated with dioctahedral montmorillonite, analcime, Kfeldspar, zeolites, and lesser secondary minerals. Donnelly et al. (1979) argue that the celadonite is an end product of the ordering of clay minerals originally formed in younger basalts, such as the clays found at DSDP Site 332 in the FAMOUS area on the Mid-Atlantic Ridge. These younger clays are chemically analogous to celadonite and give identical structural formulae, but lack mica X-ray patterns. Instead, they have X-ray patterns of smectite minerals reflecting a continuum between mixed-layer smectite and mica end-members (Robinson et al., 1977; Andrews et al., 1977). Donnelly et al. (1979) introduced the term proto-celadonite to describe these precursors. Pritchard (1979), however, argued that the precursor at Sites 417 and 418 was originally saponite but that chemical changes in the clay converted it first to dioctahedral proto-celadonite (or $1 \mathrm{Md}$ glauconite), which then transformed structurally to celadonite. Scheidegger and Stakes (1979) described X-ray criteria which led them to conclude that a K-rich, dioctahedral, mica-like mineral (proto-celadonite) actually still occurs in Holes 417D and 418A. Comparison of chemical and mineral data for old and young ocean crust suggested to them that there was a time sequence of alteration at Sites 417 and 418. Initially, nonoxidative alteration formed abundant $\mathrm{Mg}$-rich saponite. Later, oxidative alteration added considerable $\mathrm{K}$ and $\mathrm{Fe}$ to the system, leading to the formation of proto-celadonite and celadonite. Seyfried et al. (1978), however, describe quite the reverse of this sequence for alteration of basalts from DSDP Hole 321, which is in late Eocene crust on the Nazca plate. There, an early, oxidative phase of alteration produced green mica (celadonite) and iron hydroxides in vein minerals, and a later, nonoxidative, phase produced blue green iron-rich saponite. The celadonite is iron-rich, resembling that from Sites 417 and 418.

In Hole 459B, we have determined the compositions of three groups of celadonites, or celadonite-like minerals. These are compared in Figure 15 with various minerals from occurrences cited earlier. The three groups are (1) the fibrous orange clay mineral associated with iron hydroxides and palygorskite in the uppermost pillow basalts (Fig. 7), (2) the blue green bladed celadonite in the massive basalts (Fig. 8), and (3) the green celadonite replacing clinopyroxene in the massive basalts (Fig. 9 ). Of these, only the fibrous orange variety chemically resembles celadonites from Sites 417 and 418 or that from Site 321. It does not have a mica structure (Table 1 
Table 2. Electron microprobe analyses of clay minerals.

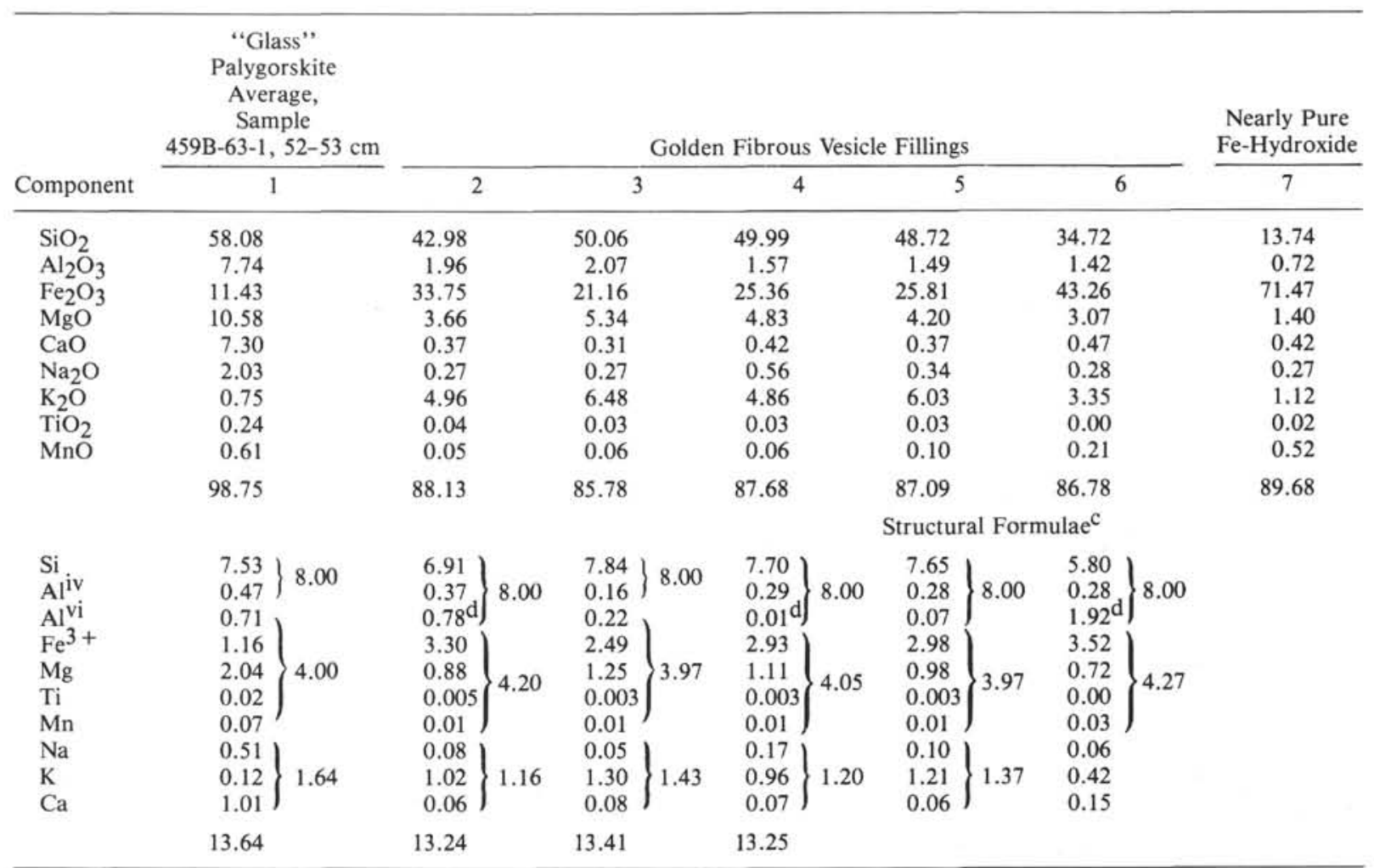

\footnotetext{
a Sample 424-1-1, 90-92 cm: representative sedimentary green mud, from Hekinian et al., 1980, table 4.

b Sample 424B-6-1, 36-39 (Piece 6): microprobe analysis of clay in vesicle in basalt, from Hekinian et al., 1980, table 5.

Cations per 22 oxygens.

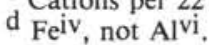

and Fig. 5), however, but appears to be an iron-rich smectite such as nontronite. It could qualify as the proto-celadonite of Donnelly et al. (1979), although it is compositionally dissimilar to genuine celadonites a few meters farther downhole which formed in a particular structural environment (massive basalts). Also, it is associated with palygorskite, which has not been found at any ocean crust DSDP site.

The fibrous orange clay mineral is also quite similar to iron-rich sedimentary clay minerals and alteration products in basalts at DSDP Site 424 , in the Galapagos Mounds geothermal field (e.g., Hekinian et al., 1978; Hekinian, et al., 1980), as shown on Table 2 (columns 15 and 16) and Figure 14. Donnelly (1980) noted that the sedimentary clays at Site $\mathbf{4 2 4}$ are similar to his protoceladonite in that their analyses give celadonite structural formulae, but their X-ray patterns are those of smectite rather than mica. Donnelly did not speculate on whether the mounds-type smectite and proto-celadonite have a similar origin, but it is remarkable how very similar the compositions of these different minerals are (Table 2). The origin of the clay minerals at the Galapagos Mounds is, of all the occurrences so far described, the one most clearly linked to hydrothermal activity in the ocean crust. Hekinian et al. (1980) infer that the mounds sediments are direct precipitates from hydrothermal solutions exiting from vents along faults in basement at perhaps $10-15^{\circ} \mathrm{C}$ (Corliss et al., 1979). However, oxygen isotope data for clay minerals which include chemically similar celadonite at Sites 417 and 418 (Muehlenbachs, 1979) and smectites with celadonite compositions from the FAMOUS area (Muehlenbachs, 1977) give temperatures of alteration in basalts of a few degrees. Most workers consequently, argue that the alteration was produced by cold seawater (e.g., Robinson et al., 1977; Humphris et al., 1980); low-temperature hydrothermal fluids similar to those at the Galapagos Mounds may not have been involved.

At Site 459 , the presence of palygorskite may be an indication that hydrothermal fluids altered the basalts. Its occurrence in marine sediments has long been known (Bradley, 1940; Nathan, 1969), but its recovery in sediments from the deep oceans in DSDP cores and in dredge hauls (Bonatti and Joensuu, 1968; Anon., 1970; Bowles et al., 1971; Drever, 1971; Donnelly and Nalli, 1973; Pimm, 1973; Gieskes et al., 1975; Vallier, 1974; Perry et al., 1976; Couture, 1977b) has led to every manner of speculation on its origin. It has variously been ascribed to detrital, authigenic, and hydrothermal origins and linked to conditions of elevated salinity. Couture (1977a) surveyed all reported occurrences and presented thermodynamic calculations to show that precipitation of palygorskite can occur from normal seawater and is favored at moderately elevated temperatures (no warmer than, say, equatorial currents impinging on shallow continental margins) and elevated $p \mathrm{H}$. The elevated temperature in particular enhances the solubility of amorphous silica, favoring formation of paly- 
Table 2. (Continued).

\begin{tabular}{|c|c|c|c|c|c|c|c|c|c|c|c|c|c|c|}
\hline \multirow{2}{*}{$\begin{array}{c}\begin{array}{c}\text { Opal(?)-Smectite } \\
\text { Mixture }\end{array} \\
8\end{array}$} & \multicolumn{4}{|c|}{$\begin{array}{l}\text { Clays } \\
\text { Replacing } \\
\text { Augite }\end{array}$} & \multicolumn{6}{|c|}{$\begin{array}{l}\text { Blue Green } \\
\text { Celadonite }\end{array}$} & & & \multicolumn{2}{|c|}{$\begin{array}{c}\text { Galapagos } \\
\text { Mounds } \\
\text { Samples }\end{array}$} \\
\hline & \multicolumn{2}{|c|}{9} & \multicolumn{2}{|l|}{10} & \multicolumn{2}{|c|}{11} & \multicolumn{2}{|c|}{12} & \multicolumn{2}{|c|}{13} & \multicolumn{2}{|c|}{14} & $15^{\mathrm{a}}$ & $16^{\mathrm{b}}$ \\
\hline 69.81 & 53.15 & & \multicolumn{2}{|l|}{46.61} & \multicolumn{2}{|l|}{43.78} & \multicolumn{2}{|l|}{45.30} & \multicolumn{2}{|l|}{43.00} & \multicolumn{2}{|l|}{50.64} & 49.35 & 45.7 \\
\hline 0.80 & 3.44 & & \multicolumn{2}{|l|}{3.22} & 4.34 & & \multicolumn{2}{|l|}{3.18} & 3.08 & & \multicolumn{2}{|l|}{3.37} & 0.52 & 4.8 \\
\hline 12.31 & 17.90 & & \multirow{2}{*}{\multicolumn{2}{|c|}{17.40}} & 15.82 & & \multicolumn{2}{|l|}{13.14} & 13.49 & & \multicolumn{2}{|l|}{16.17} & 30.38 & 28.56 \\
\hline 1.28 & 6.75 & & 6.38 & & 8.29 & & \multicolumn{2}{|l|}{5.55} & 5.39 & & \multicolumn{2}{|l|}{7.18} & 2.37 & 4.6 \\
\hline 0.17 & 0.18 & & \multicolumn{2}{|l|}{1.71} & 0.23 & & \multicolumn{2}{|l|}{0.22} & 0.12 & & \multicolumn{2}{|l|}{0.12} & 0.05 & $<0.6$ \\
\hline 0.13 & 0.05 & & \multicolumn{2}{|l|}{0.18} & 0.60 & & \multicolumn{2}{|l|}{0.14} & 0.07 & & \multicolumn{2}{|l|}{0.28} & - & $<0.5$ \\
\hline 2.06 & 7.72 & & \multicolumn{2}{|l|}{5.32} & 4.38 & & 6.35 & & 6.64 & & 7.25 & & 2.27 & 6.4 \\
\hline 0.03 & 0.10 & & 0.26 & & 0.13 & & 0.05 & & 0.06 & & 0.08 & & 0.03 & - \\
\hline 0.07 & 0.10 & & 0.19 & & 0.15 & & 0.18 & & 0.16 & & 0.19 & & 0.14 & $<0.5$ \\
\hline 86.66 & 89.39 & & 81.27 & & 77.72 & & 74.14 & & 72.01 & & 85.28 & & 85.11 & 91.66 \\
\hline & & & & & Stru & ctural & Formulae & & & & & & & \\
\hline & $\begin{array}{l}7.90 \\
0.10\end{array}$ & 8.00 & $\begin{array}{l}7.65 \\
0.35\end{array}$ & 8.00 & $\left.\begin{array}{l}7.44 \\
0.56\end{array}\right\}$ & 8.00 & 8.04 & & $\left.\begin{array}{l}7.92 \\
0.08\end{array}\right\}$ & 8.00 & $\begin{array}{l}7.87 \\
0.13\end{array}$ & 8.00 & & \\
\hline & 0.50 & & 0.27 & & 0.31 ) & & 0.67 , & & 0.59 & & 0.49 & & & \\
\hline & 2.00 & & 2.15 & & 2.02 & & 1.76 & & 1.87 & & 1.89 & & & \\
\hline & 1.50 & 4.02 & 1.56 & 4.04 & 2.10 & 4.57 & 1.47 & 3.94 & 1.48 & 3.97 & 1.66 & 4.08 & & \\
\hline & 0.01 & & 0.03 & & 0.22 & & 0.01 & & 0.01 & & 0.01 & & & \\
\hline & 0.01 & & 0.03 & & $0.02^{\prime}$ & & 0.03 & & $0.02)$ & & 0.03 & & & \\
\hline & 0.01 & & 0.06 & & 0.201 & & 0.051 & & 0.03 & & 0.08 & & & \\
\hline & 1.46 & 1.50 & 1.11 & 1.47 & 0.95 & 1.19 & 1.44 & 1.53 & 1.56 & 1.61 & 1.44 & 1.72 & & \\
\hline & 0.03 & & 0.30 J & & 0.04 J & & 0.04 & & $0.02 J$ & & $0.20 J$ & & & \\
\hline
\end{tabular}

gorskite at the expense of montmorillonite. Couture (1977a) also concluded that palygorskite could be derived from any unstable reactive aluminosilicate and suggested that both basaltic and siliceous volcanic ash could be important palygorskite precursors.

The common thread that runs through the various palygorskite occurrences seems to be that both magnesian and siliceous components are available for reaction, or can be readily inferred to have been available. Couture (1977a) lists a number of DSDP sediment occurrences where the bulk sediments are mainly magnesian clays. Nearshore occurrences which have been attributed to elevated salinity are associated with refluxproduced dolomites (e.g., Weaver and Pollard, 1973). Sepiolite and/or palygorskite commonly occur in clayrich marine sediments that are associated with cherts and have abundant clinoptilolite (an authigenic zeolite common in siliceous marine sediments or sediments with siliceous volcanic ash; Stonecipher, 1976) and an abundant radiolarian or diatomaceous fraction. In most of these instances, the $\mathrm{Mg}$ is evidently supplied by seawater or brines. In some instances, however, it actually occurs in solids from which it may be derived. Hathaway and Sachs (1965) describe dredged clay-rich materials containing montmorillonite, clinoptilolite, quartzose chert, and veins in sepiolite from the Mid-Atlantic Ridge. The clays, they believe, were derived from volcanic ash produced by submarine volcanic activity. Bonatti and Joensuu (1968) describe dredged boulders encrusted with manganese oxides made up of a mixture of sedimentary and igneous material. In addition to palygorskite and traces of sepiolite, the boulders include the siliceous minerals clinoptilolite and quartz and the magnesian minerals serpentine and dolomite. These authors ascribe the formation of palygorskite and sepiolite to the action of hydrothermal fluids on volcanic ash, but their argument is circumstantial.

Couture (1977a) concluded that palygorskite and sepiolite typically form authigenically by reaction of magnesian and siliceous components in sediments in the presence of seawater or more saline brines. In his experiments, however, sepiolite actually precipitated from seawater saturated with opaline silica at $25^{\circ} \mathrm{C}$. Earlier, Seiffert and Wey (1962) precipitated fibrous sepiolite from highly alkaline, silica-rich $\mathrm{MgCl}_{2}$ solutions in the laboratory. These experiments demonstrate that sepiolite and, inferentially, palygorskite, could form directly from solutions in nature. These experiments seem especially applicable to the occurrences at Site 458 and 459 , since vein-filling palygorskite must have been a direct precipitate from formation fluids.

It is important to establish why palygorskite formed rather than other, more common magnesian clay minerals such as saponite, talc, or chlorite. Palygorskite is more siliceous than these minerals and has a much higher ratio of ferric to ferrous iron. Our particular example is also less magnesian. These characteristics do not appear to stem particularly from the compositions of the host basalts, which are not greatly different from seafloor basalts. Although the basalts in Hole 459B are related to the island arc tholeiite suite (e.g., Wood et al., this volume) and include some highly fractionated compositions, they are no more siliceous or iron-enriched than typical fractionated abyssal tholeiites (i.e., East Pacific 

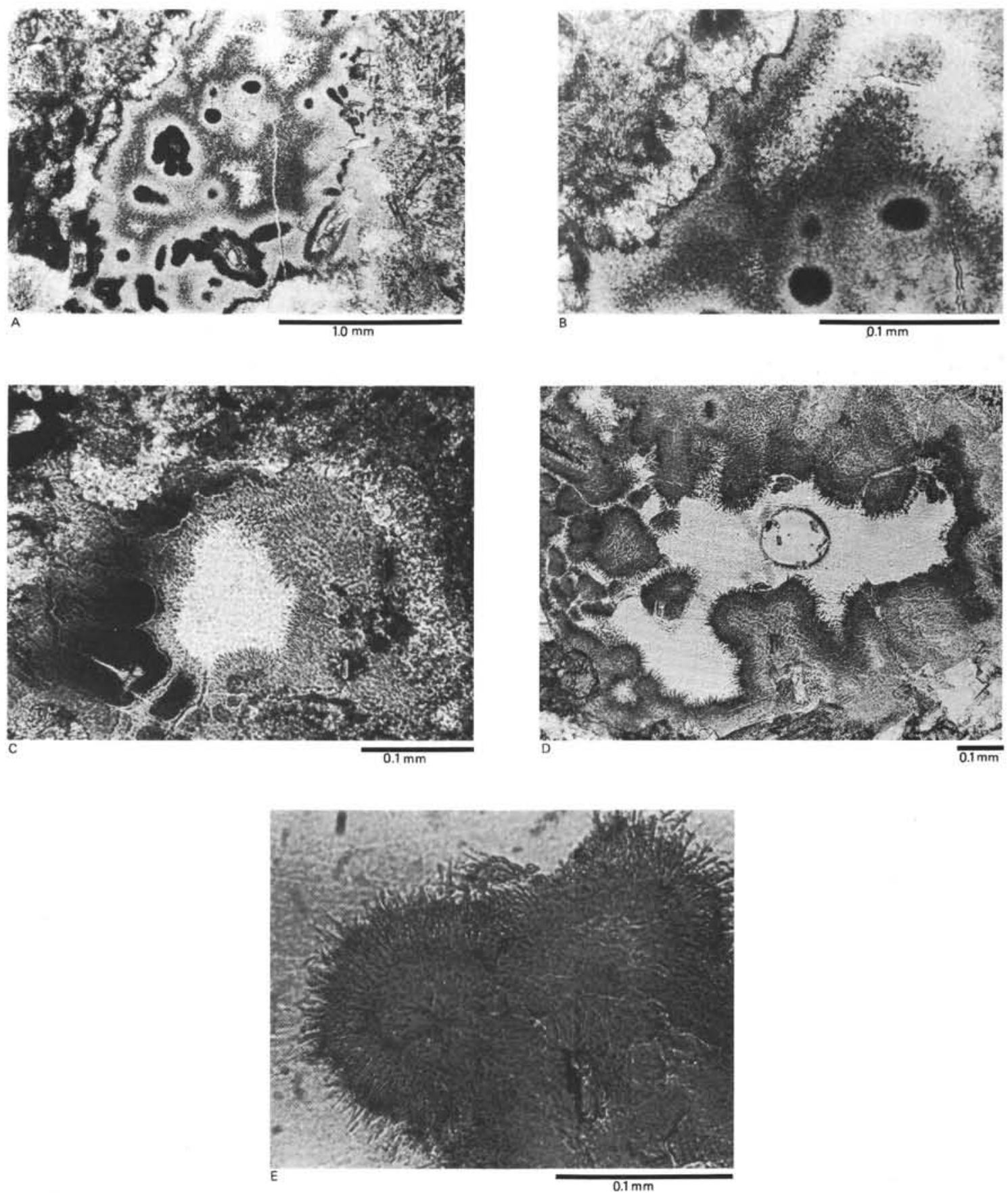

Figure 7. Iron-rich smectite and associated iron hydroxides lining cavities in basalts of Hole 459B. A-C are of Sample 459B-61-1, 126-129 cm. B is a blowup of a portion of A. The clear material at left is pale yellow and silica-rich, possibly a combination of opal and clays (see text and Table 3). The dark spots are reddish iron hydroxides. These have a botryoidal habit in C. D and E are of Sample 459B-61-1, 126-129 cm. E is a blowup of a portion of D showing the finely fibrous habit of these smectites.

Rise or Galapagos Rift ferrobasalts; Clague and Bunch, 1976; Natland and Melson, 1980). They are quite a bit less magnesian than most Mid-Atlantic Ridge tholeiites, with $\mathrm{MgO}$ as low as $4.6 \%$ in some samples. $\mathrm{Mg}$ for the clay minerals, then, was supplied by the formation fluids.

From the various ocean crust occurrences cited earlier, saponite is the usual low-temperature nonoxidative magnesian secondary mineral found in young seafloor ba- salts. Increasing the availability of oxygen usually results in the formation of other smectites, including ferric nontronite (Scheidegger and Stakes, 1977, 1979). Increasing the temperature results in the formation of mixed-layer clays and chlorite instead of saponite between about $100^{\circ} \mathrm{C}$ and $150^{\circ} \mathrm{C}$ (Tomasson and Kristmannsdottir, 1972; Humphris and Thompson, 1978; Mottl and Holland, 1978; Cann, 1979; Natland and Hekinian, this volume). In the presence of excess silica, 

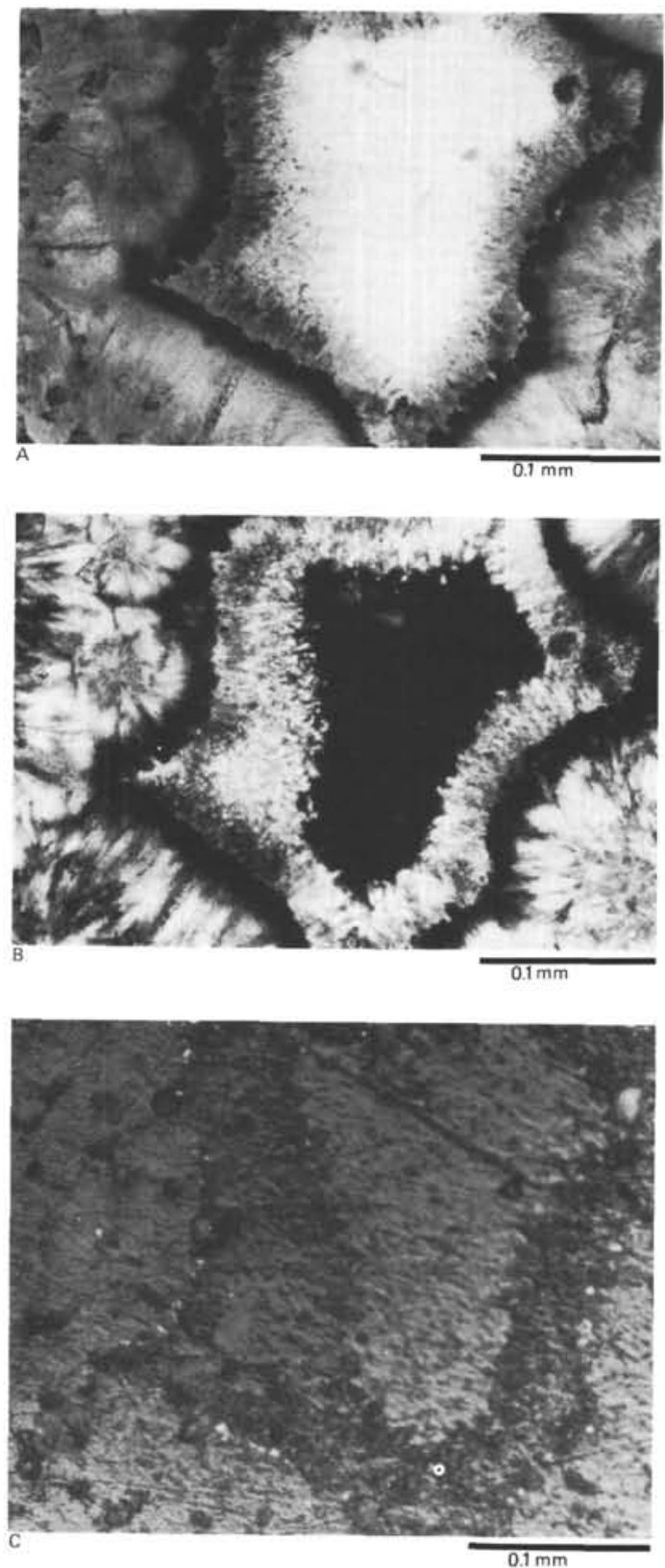

Figure 8. Associated iron hydroxides and smectites in a cavity within Sample 459B-71-2, 15-16 cm, shown in three views: A, plane-polarized light, B, crossed nichols, $\mathrm{C}$, reflected light. The outer, densely packed, clays are green; the inner, loosely clumped, clays are orange. They are separated by a thin layer of reddish iron hydroxides, which have moderate reflectivity (C).

warm magnesian hydrothermal solutions that have reacted with basalts evidently produce talcose precipitates (Murdmaa and Rozanove, 1976; Lonsdale et al., 1980).

Our data suggest that palygorskite may be an analog to these various magnesian minerals at appropriately elevated temperature and $p \mathrm{H}$ and, most significantly, high Eh. All the other minerals-saponite, chlorite, and talc-have compositions, structural formulae, or associated minerals such as pyrite, indicating that they formed in prevailing reducing conditions. Experiments in which palygorskite or sepiolite has formed from basalts reacted with seawater at various rock:water ratios have generally been undertaken in fairly reducing conditions $\left(\mathrm{O}_{2}\right.$-buffered in sealed capsules). The laboratory experiments in which sepiolite was precipitated were open to atmospheric oxygen. Conditions of palygorskite formation in Hole 459B were oxidative, as evidenced by the abundance of iron hydroxides and the structural formulae of both celadonite and palygorskite, in which all iron is calculated as ferric.

If the experimental indication is correct that palygorskite formation is favored at high $p \mathrm{H}$, it would also be atypical of alteration in the ocean crust, at least at elevated temperatures. High-temperature hydrothermal vents at the crest of the East Pacific Rise at $21^{\circ} \mathrm{N}$ seem to be quite acid ( $p \mathrm{H}=4.7$; Edmond, 1981). The situation at Site 459 may have been more akin to conditions of formation of some palagonites, wherein extensive leaching of silica and other components from basaltic glass results in pore fluids with extremely high $p \mathrm{H}$ (e.g., Hay and Ijima, 1968). Presently, however, we favor the interpretation that palygorskite formation in Hole 459B occurred under oxidative conditions (as evidenced by the mineral associations and compositions), probably at moderately elevated temperatures (as evidenced by experimental data and by the occurrence of smectites similar to those of the Galapagos Mounds). The inference about $p \mathrm{H}$ is by analogy with experiments only.

Under these conditions, formation of palygorskite and associated minerals probably occurred shortly after basalt extrusion, when warm solutions may still have been venting from the crust, and before sediment burial sealed off pore fluids in the basalts from exchange with oxygenated seawaters. Desprairies et al. (this volume) report that palygorskite occurs in sediments immediately above basalts in Hole 459B. These sediments have a reddish brown color reminiscent of hydrothermally produced basal sediments at many DSDP ocean crust sites.

We speculate that the green smectite-phillipsite association in Hole 459B formed after sufficient sediments had accumulated to limit the availability of oxygen in basement. The high concentrations of these minerals along slickensided zones of intense fracturing suggest that this later phase of alteration occurred during episodes of faulting. Although detailed structure of faults cannot be worked out in the basement basalts because they are so broken up, there are numerous healed microfaults in the older sediments of Hole 459B above basalts. These suggest that most of the faults were highangle normal faults (see Site 459 report, this volume). Air-gun profiles near both Sites 458 and 459 , but especially near the latter site, show considerable block (i.e., normal) faulting in the fore-arc region, increasingly prominent toward the trench/slope break, which is near Site 459 (Hussong and Fryer, this volume). We therefore suggest that secondary fluids migrated along these faults to produce the nonoxidative alteration in Hole 459B. Most of the smectites in Hole 458 basalts are dioctahedral, implying that alteration there was somewhat more oxidative, but the general pattern of intense alteration 

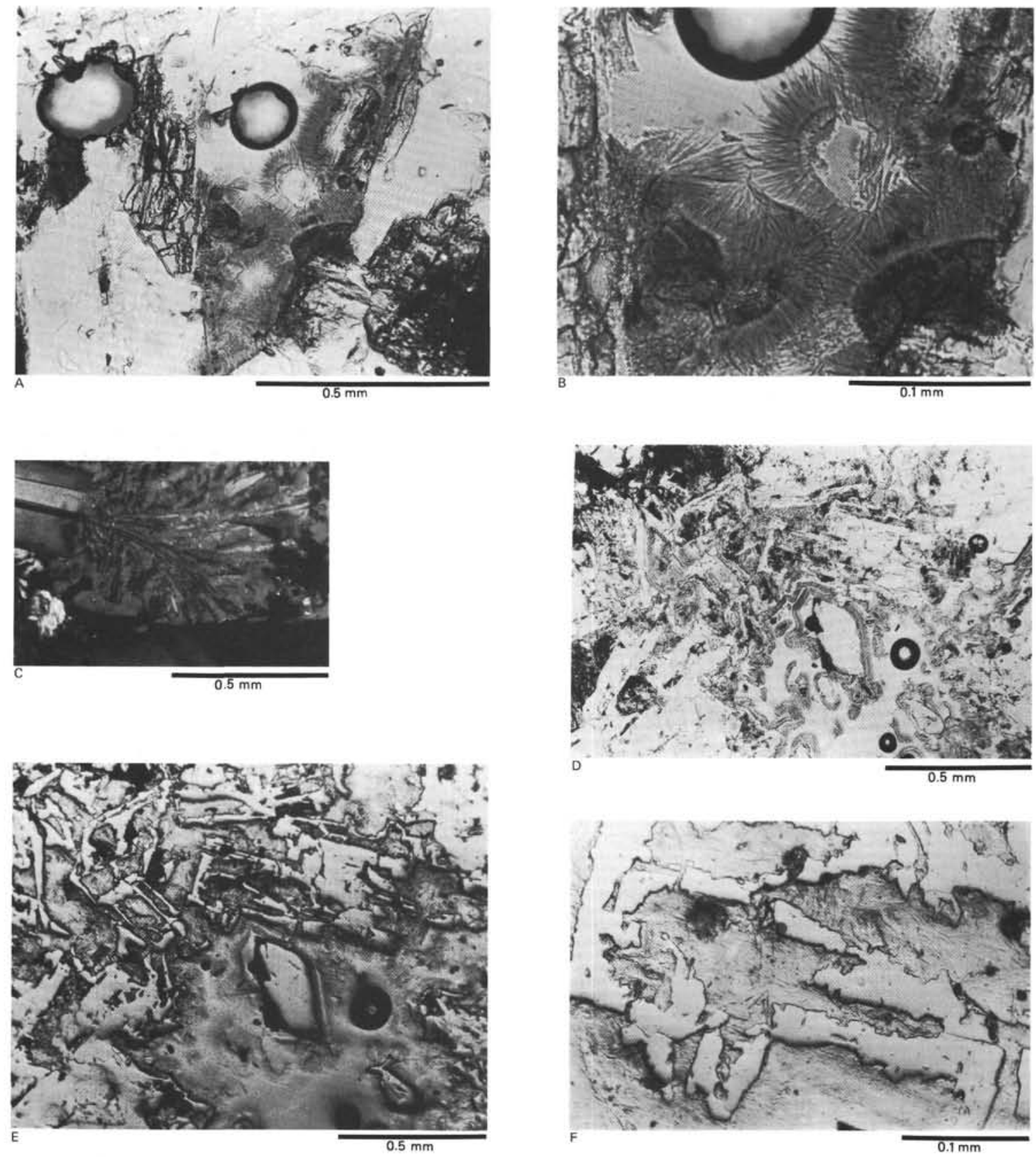

Figure 9. Celadonite in coarse-grained basalt. All photomicrographs are from Sample 459B-66-3, 3-4 cm. The celadonite lines cavities between mineral grains in the basalt, as in A. The primary silicates are plagioclase, augite, and quartz, in plane-polarized light. B is a detail of a portion of A, also in plane light. C shows a coarse plagioclase-quartz spherulitic intergrowth in the same sample, in crossed nichols. D shows pervasive distribution of celadonite in a larger portion of this basalt, in plane-polarized light. E shows the extent of fresh minerals (high relief) and altered zones (low relief) in the same portion of the rock in reflected light. $\mathrm{F}$ is a detail of a portion of $\mathrm{E}$ showing extensive corrosion of the edges of the feldspar grains by alteration, in reflected light.

along zones of fractured basalt is the same as in Hole 459B. Perhaps thinner sediments there acted as a less perfect barrier to exchange between pore fluids and oxygenated seawater. Takagami and Ozima (this volume) report a possible age of alteration at Site 458 based on ${ }^{40} \mathrm{Ar} /{ }^{39} \mathrm{Ar}$ incremental heating techniques of $\sim 20 \mathrm{~m}$.y. Their determination was performed on a sample from a highly fractured interval of basalts in Core 41 (chemical type $B_{1}$, Fig. 4). This is $10-14$ m.y. younger than the estimated age of basement at the site based on nannofossils (Ellis, this volume).

There is little doubt that the faulting in the fore-arc region is somehow related to subduction of the Pacific plate. The detailed mechanisms of faulting at any particular location are still unknown, however, inasmuch as the relative roles of subduction, accretion, obduction, and possible downdropping of fault blocks on the arc side into the Mariana Trench are not known. Prob- 

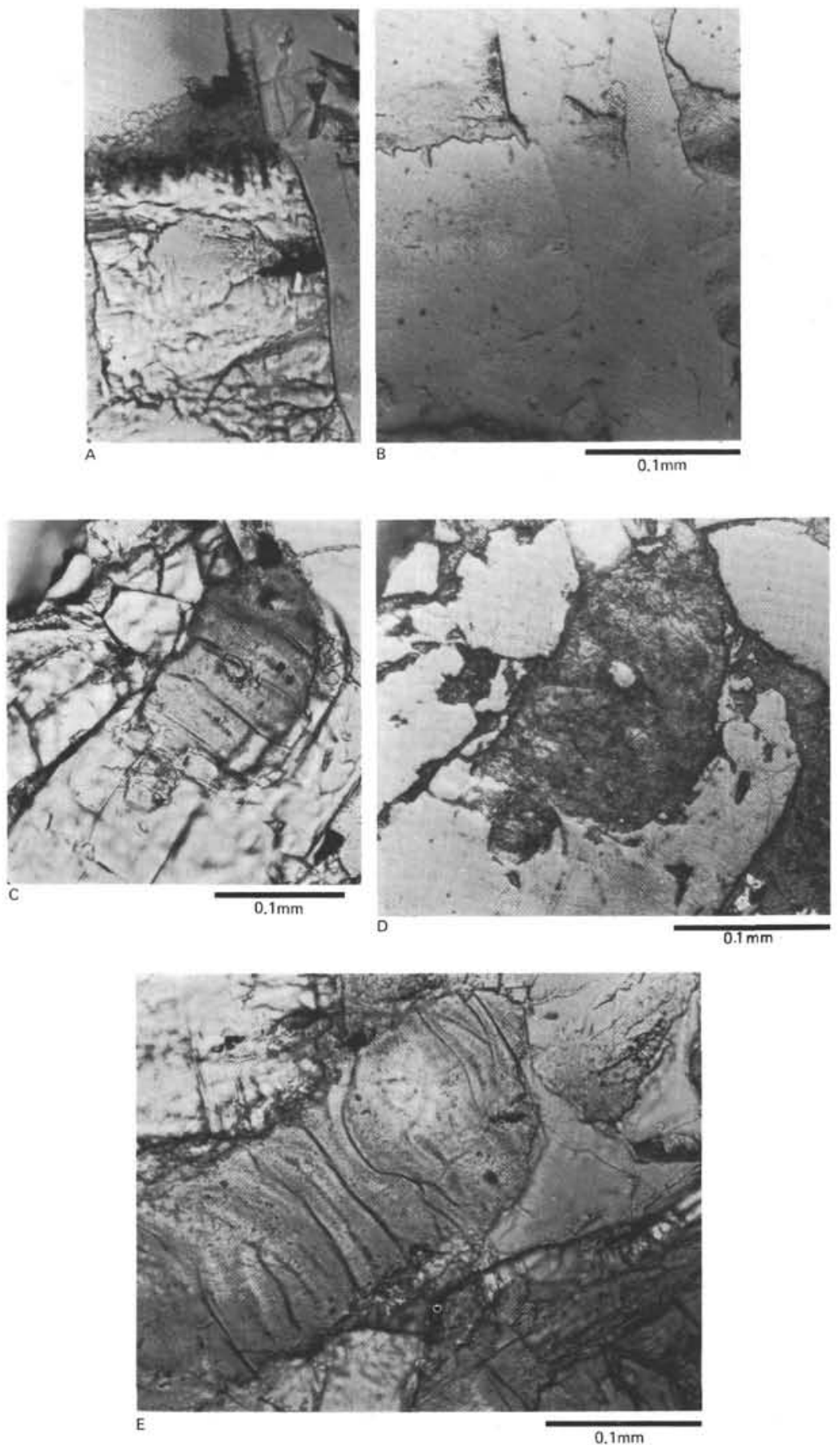

Figure 10. Examples of alteration affecting augite. A and B are views of an augite from Sample 459B-66-3, 3-4 cm in plane-polarized and reflected light showing how the edge of the crystal has altered to clays. $C$ and $D$ are plane-polarized and reflected-light views of an augite in Sample 459B-67-1, 106-107 cm showing large-scale transformation of the pyroxene to dark green celadonite. E shows a pyroxene in the same sample entirely replaced by celadonite, in plane-polarized light.

ably the faulting in and around Hole 459B is related to downdropping (Hussong and Fryer, this volume), but the origin of the elevated basement feature on which Site 458 was drilled remains enigmatic. The nonoxidative fluids that altered basalts to smectite-phillipsite assemblages in Hole 459B, however, were not seawater, and we consider it entirely likely that they were derived from the subducting slab by sudden compression of its fluid-saturated sediments and upper ocean crust.

It is tempting to speculate that the earlier stage of alteration, in which palygorskite figured so prominently, is also related to subduction. In fact, Desprairies et al. (this volume) report palygorskite (attapulgite) in sediments associated with serpentinite grains drilled at 

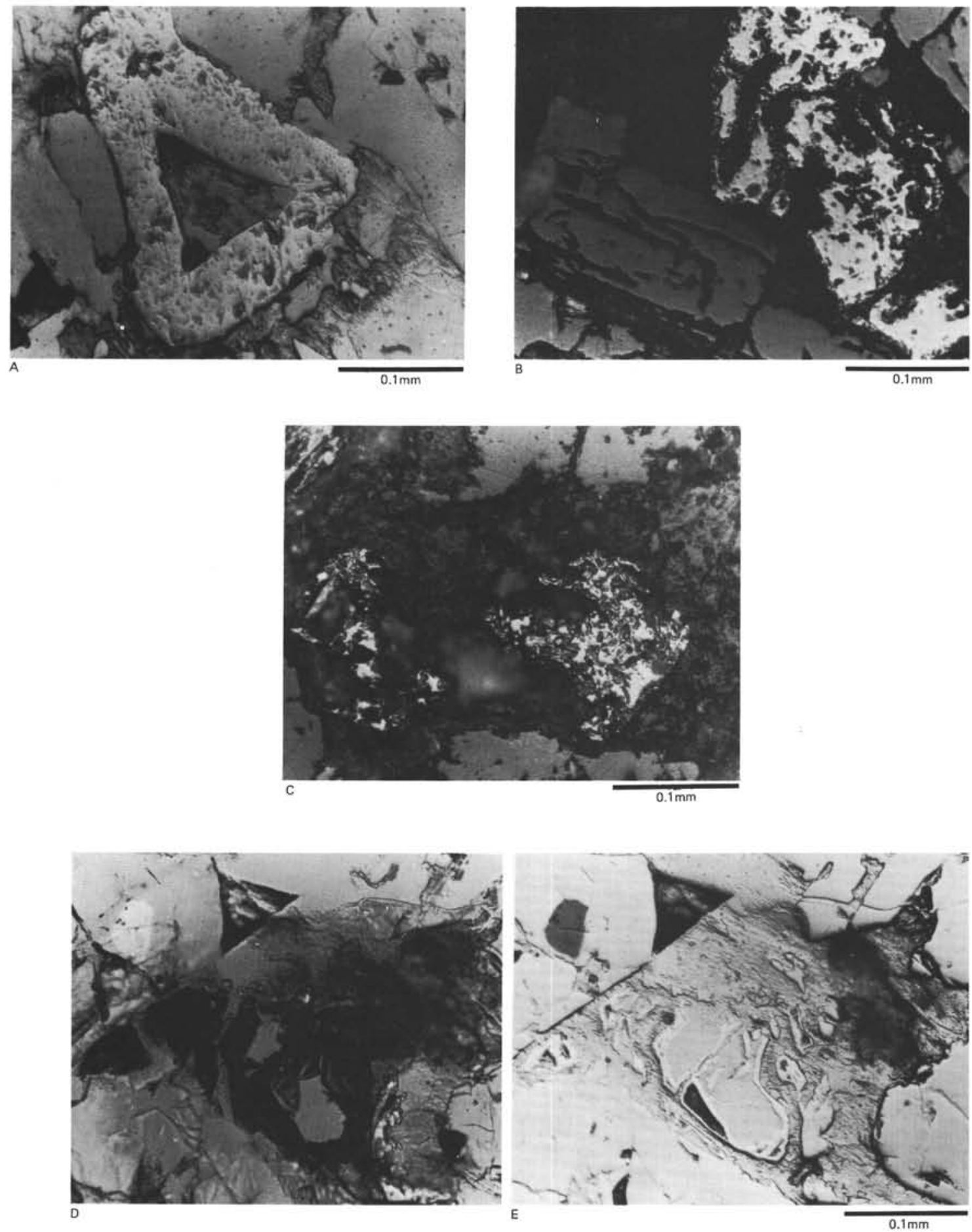

Figure 11. A-C. Pitted and altered skeletal titanomagnetite grains in coarse-grained basalts, all in reflected light. A. Sample 459B-66-3, 3-5 cm. B. Sample 459B-66-2, 4-7 cm. C. Sample 459B-67-1, 106-107 cm. D and E are plane-polarized and reflected-light views of iron hydroxides and clays replacing an interstitial ferromagnesian silicate, perhaps an iron-rich olivine, in Sample 459B-66-3, 3-4 cm.

Site 460, deep in the Mariana Trench. Palygorskite is thus not an isolated occurrence but is known at three localities, two unequivocally in basement, in the Mariana fore-arc region. We cannot yet say what specifically promotes this type of alteration in the fore-arc tectonic regime, but we can speculate that the fluids which caused the alteration were derived from dehydration of the subducting ocean sediments and basement and thus had compositions modified considerably from that of seawater before dehydration. The fluids also may have migrated upward through considerable thicknesses of ultramafic rock (e.g., Evans and Hawkins, 1979; Hawkins et al., 1979) and perhaps sediments, materials not normally encountered in ocean crust hydrothermal cir- 

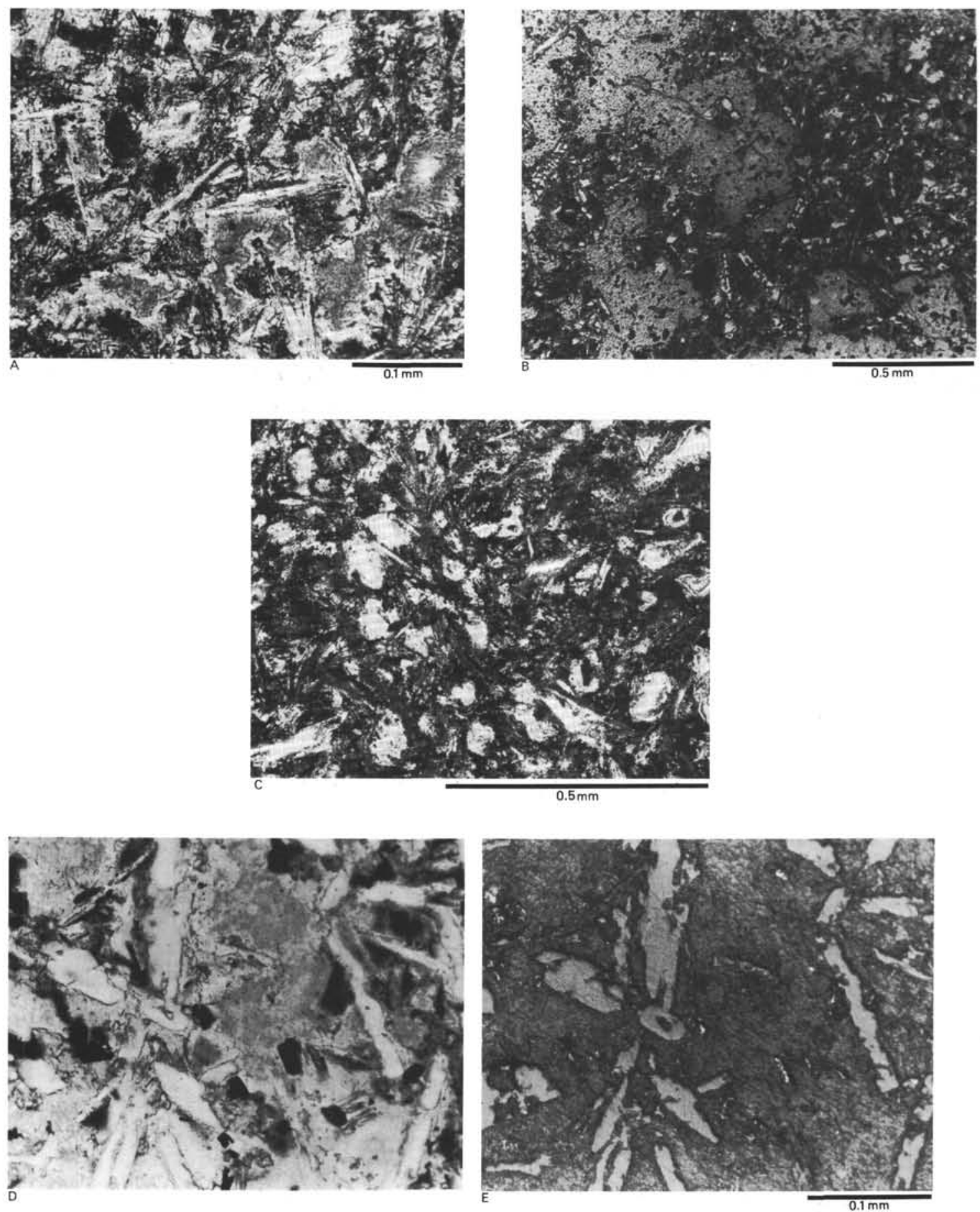

Figure 12. Pervasive groundmass alteration in fine- to medium-grained basalts, Hole 459B. A. Pale green clays replacing glass between plagioclase in formerly hyalopilitic basalt, plane-polarized light. Sample 459B-63-1, 81-83 cm. B. Uniform, mat-like pale green to orange clays replacing portions of Sample 459B-71-2, 15-16 cm, in plane-polarized light. C. Vesicles (round to irregular light patches) filled with pale green clays, Sample 459B-63-1, 24-27 cm, plane-polarized light. $\mathrm{D}$ and $\mathrm{E}$ are two views of the same sample, 459B-70-1, 69-71 cm, in plane-polarized and reflected light, showing the extent of groundmass alteration to pale green clays in a subophitic sample. Only the plagioclases and traces of titanomagnetites have not been replaced by clays. This is especially evident in E, where the clays are dark gray, have low relief in reflected light, and make up about $70 \%$ of the sample. 

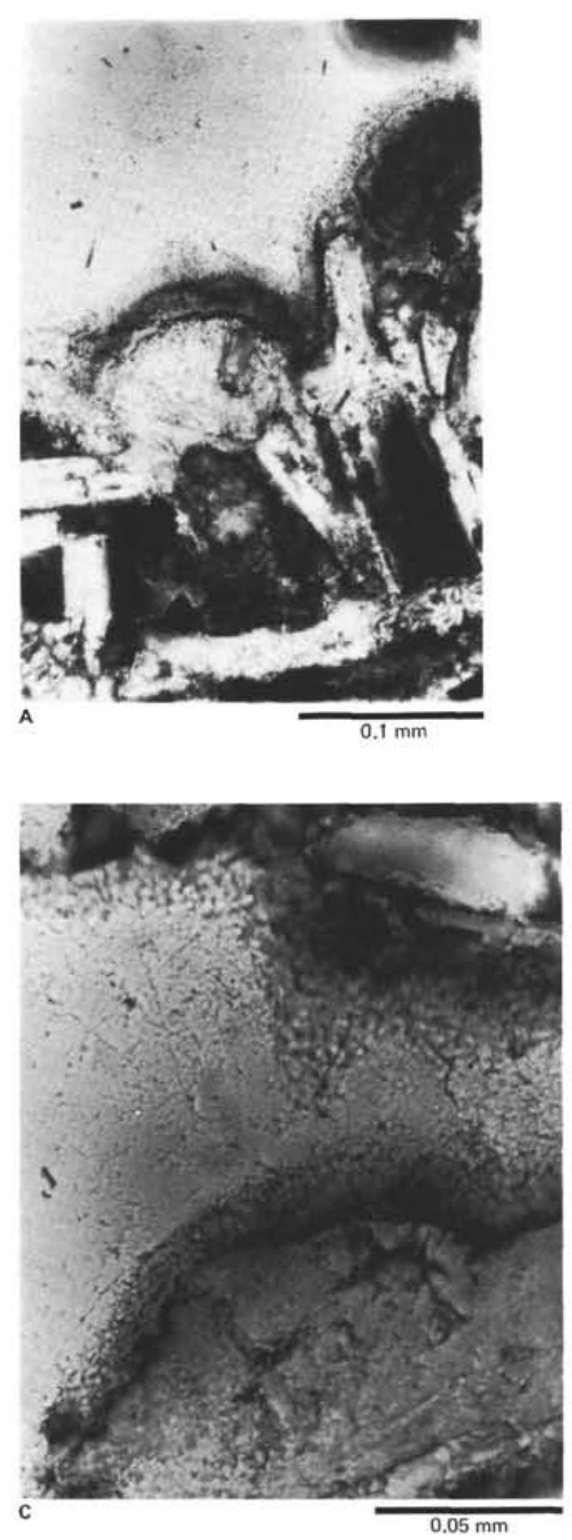
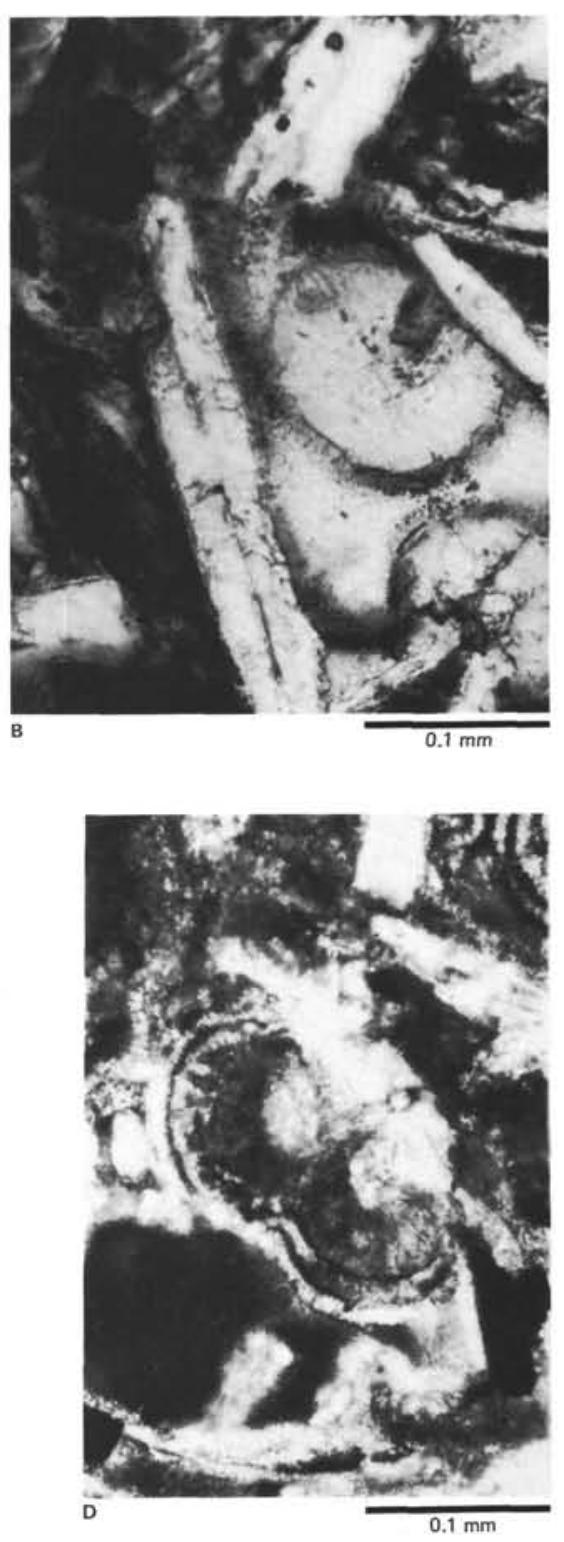

Figure 13. Phillipsite and pale green clays in selected samples, Hole 459B. The phillipsite forms rosettes radiating into cavities and is coated with fuzzy olive green clays. A and D are Sample 459B-69-1, 3-5 cm. B and C are Sample 459B-70-1, 40-42 cm. All are in plane-polarized light except $\mathrm{D}$, which was photographed with nichols crossed.

Table 3. X-ray power data for typical palygorskite samples, Hole 459B.

\begin{tabular}{ccccc}
\hline & & \multicolumn{3}{c}{ Sample } \\
\cline { 3 - 5 } hkl & $\begin{array}{c}d(\AA) \\
\text { (Bowles et al., 1971) }\end{array}$ & $\begin{array}{c}d(\AA) \\
62-1(79-80)\end{array}$ & $\begin{array}{c}d(\AA) \\
61-2(95-97)\end{array}$ & $\begin{array}{c}d(\AA) \\
61-2(76-77)\end{array}$ \\
\hline 110 & 10.5 & 11.0 & 11.0 & 10.9 \\
200 & $6.38-6.44$ & 6.32 & 6.33 & 6.32 \\
130 & 5.42 & 5.16 & - & 5.06 \\
040 & 4.49 & 4.44 & 4.46 & 4.41 \\
310 & 4.18 & 4.20 & 4.27 & 4.21 \\
240 & 3.69 & 3.66 & 3.67 & - \\
330,150 & 3.50 & - & - & 3.56 \\
400 & 3.23 & 3.21 & 3.20 & 3.18 \\
420 & 3.03 & 3.01 & 3.02 & 3.00 \\
440 & 2.61 & 2.61 & 2.61 & 2.60 \\
510 & 2.55 & 2.53 & 2.53 & 2.52 \\
080 & 2.24 & - & 2.27 & 2.26 \\
\hline
\end{tabular}

culation near ridge crests. There, fluid circulation extends downward into the crust to depths of perhaps 5 km (Lister, 1974; Wolery and Sleep, 1976) and therefore occurs predominantly in basaltic and gabbroic rocks.

\section{CONCLUSIONS}

We have described a new type of alteration in igneous rocks primarily from Hole 459B in the Mariana fore-arc region. Central to this type of alteration is the formation of palygorskite along with an oxidative mineral assemblage including iron-rich smectite, celadonite, and iron hydroxides. Later, alteration was concentrated along zones of intense fracturing in basalts of both Holes 458 and 459B, resulting in formation of di- and trioctahedral smectites, respectively, plus phillipsite. The faulting and alteration considerably postdate lava 


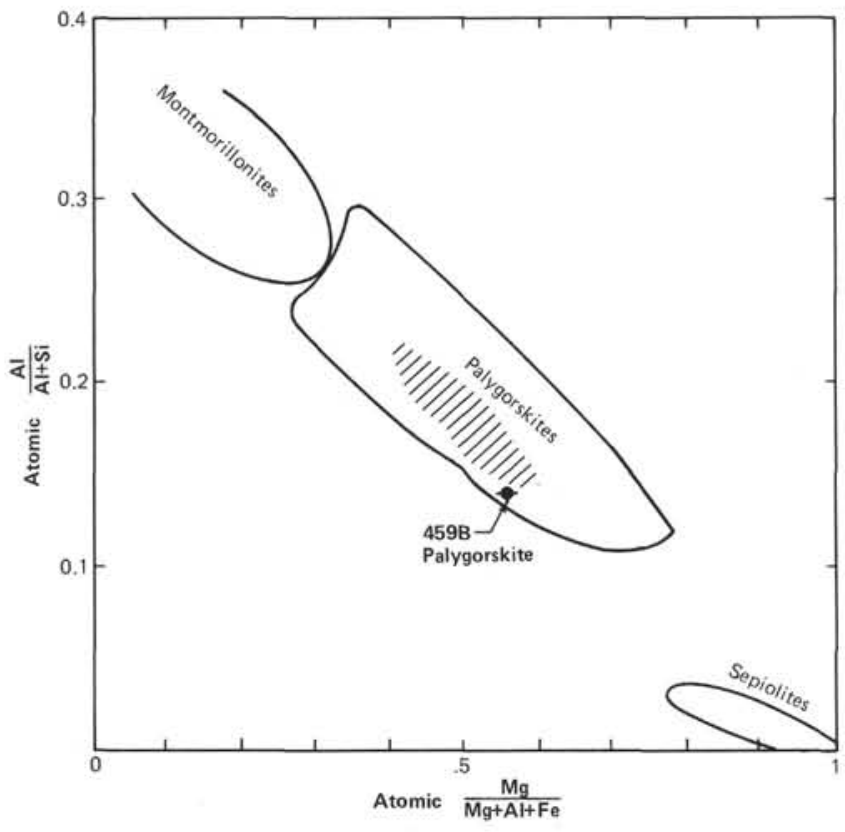

Figure 14. Atomic $\mathrm{Mg} / \mathrm{Mg}+\mathrm{Mg}+\mathrm{Al}+\mathrm{Fe}$ versus atomic $\mathrm{Al} / \mathrm{Al}+$ $\mathrm{Si}$, after Couture (1977a). Sepiolite field is from Grim (1968). Diagonal field is that of marine palygorskites.

emplacement, and the alteration may have been caused by fluids partly derived from the subducting ocean crust and sediments beneath the sites.

\section{ACKNOWLEDGMENTS}

Costs for this study were defrayed by Cruise Activities funds allocated to Leg 60 by the Deep Sea Drilling Project. We are grateful to D. Hussong and Y. Lancelot for making those funds available. We also thank $\mathrm{H}$. Fujita for assistance with the microprobe work and $\mathrm{E}$. Flentye for keeping the SEM under control. Miriam Kastner provided considerable guidance and advice concerning verification of minerals by X-ray diffraction. Joris Gieskes reviewed the manuscript.

\section{REFERENCES}

Andrews, A. J., 1977. Low-temperature fluid alteration of oceanic layer 2 basalts, DSDP Leg 37. Can. J. Earth Sci., 14:911-926.

Andrews, A. J., Barnett, R. L., MacClement, B. A. E., et al., 1977. Zeolite facies metamorphism, geochemistry, and some aspects of trace element redistribution in altered basalts of DSDP Leg 37. In Aumento, F., Melson, W. G., et al., Init. Repts. DSDP, 37: Washington (U.S. Govt. Printing Office), 795-810.

Anonymous, 1970. 14-MEV neutron activation analysis of selected Leg 2 core samples. In Peterson, M. N. A., Edgar, N. T., et al., Init. Repts. DSDP, 2: Washington (U.S. Govt. Printing Office), 347-348.

Bass, M. N., 1976. Secondary minerals in oceanic basalts with special reference to Leg 34, Deep Sea Drilling Project. In Yeats, R. S., Hart, S. R., et al., Init. Repts. DSDP, 34: Washington (U.S. Govt. Printing Office), 393-432.

Bonatti, E., and Joensuu, O., 1968. Palygorskite from Atlantic deep sea sediments. Am. Mineral., 53:975-983.

Bowles, F. A., Angino, E. A., Hosterman, J. W., et al., 1971. Precipitation of deep-sea palygorskite and sepiolite. Earth Planet. Sci. Lett., 11:324-332.

Bradley, W. F., 1940. Structure of attapulgite. Am. Mineral., 25: 405-410.

Cann, J. R., 1979. Metamorphism in the ocean crust. In Talwani, M., Harrison, C., and Hayes, D. (Eds.), Deep Drilling Results in the Atlantic Ocean: Ocean Crust, Maurice Ewing Series 2: Washington (American Geophysical Union), pp. 230-238.
Clague, D. A., and Bunch, T. E., 1976. Formation of ferrobasalt at east Pacific midocean spreading centers. J. Geophys. Res., 81: 4247-4256.

Corliss, J. B., Dymond, J. R., Gordon, L. I., et al., 1979. Submarine thermal springs on the Galapagos Rift. Science, 203:1073-1083.

Couture, R. A., 1977 a. Synthesis of some clay minerals at $25^{\circ} \mathrm{C}$ : Palygorskite and sepiolite in the oceans [Ph.D. dissert.]. University of California, San Diego. , 1977b. Composition and origin of palygorskite-rich and montmorillonite-rich zeolite-containing sediments from the $\mathrm{Pa}$ cific Ocean. Chem. Geol., 19:113-130.

Donnelly, T. W., 1980. Secondarily modified sediments of the eastern Pacific: major-element chemistry of Sites 420, 424, and 425 Deep Sea Drilling Project Leg 54. In Rosendahl, B. R., Hekinian, R., et al., Init. Repts. DSDP, 54: Washington (U.S. Govt. Printing Office), 329-338.

Donnelly, T. W., and Nalli, G., 1973. Mineralogy and chemistry of Caribbean sediments. In Edgar, N. T., Saunders, J. B., et al., Init. Repts. DSDP, 15: Washington (U.S. Govt. Printing Office), 929-962.

Donnelly, T. W., Pritchard, R. A., Emmermann, R., et al., 1979. The aging of oceanic crust: Synthesis of the mineralogical and chemical results of Deep Sea Drilling Project Legs 51 through 53. In Donnelly, T. W., Francheteau, J., Bryan, W. B., Robinson, P., Flower, M., Salisbury, M., et al., Init. Repts. DSDP, 51, 52, 53, Pt. 2: Washington (U.S. Govt. Printing Office), 1563-1577.

Drever, J. I., 1971. Chemical and mineralogical studies, Site 66. In Winterer, E. L., Ewing, J. I., et al., Init. Repts. DSDP, 17: Washington (U.S. Govt. Printing Office), 965-976.

1974. The magnesium problem. In Goldberg, E. D. (Ed.), The Sea (Vol. 5): New York (Wiley), 337-357.

Edmond, J. M., 1981. The chemistry of ridge crest hydrothermal activity. In Presnall, D. C., Hales, A. L., and Frey, F. A. (convenors), AGU Chapman Conference: The generation of the Oceanic Lithosphere Program. (Abstract)

Evans, C., and Hawkins, J. W., 1979. Mariana arc-trench system: Petrology of "seamounts on the trench-slope break. Eos, 60:968. (Abstract)

Gieskes, J., Kastner, M., and Warner, T. B., 1975. Evidence for extensive diagenesis, Madagascar Basin, Deep Sea Drilling Site 245. Geochim. Cosmochim. Acta, 39:1385-1393.

Grim, R. E., 1968. Clay Mineralogy: New York (McGraw-Hill).

Hathaway, J. C., and Sachs, P. L., 1965. Sepiolite and clinoptilolite from the Mid-Atlantic Ridge. Am. Mineral., 50:852-867.

Hawkins, J., Bloomer, S., Evans, C., et al., 1979. Mariana arc-trench system: Petrology of the inner trench wall. EOS, 60:968.

Hay, R. L., and Ijima, A., 1968. Nature and origin of palagonite tuffs of the Honolulu Group on Oahu, Hawaii. Geol. Soc. Am. Mem., 116:331-376.

Hekinian, R., Rosendahl, B. R., Cronan, D. S., et al., 1978. Hydrothermal deposits and associated basement rocks from the Galapagos spreading center. Oceanol. Acta, 1:473-482.

Hekinian, R., Rosendahl, B. R., and Natland, J. H., 1980. Ocean crust geothermal processes: A perspective from the vantage of Leg 54 drilling. In Rosendahl, B., Hekinian, R., et al., Init. Repts. DSDP, 54: Washington (U.S. Govt. Printing Office), 395-422.

Humphris, S. E., and Thompson, R. N., 1978. Hydrothermal alteration of oceanic basalts by seawater. Geochim. Cosmochim. Acta, 42:107-125.

Humphris, S. E., Thompson, R. N., and Marriner, G. F., 1980. The mineralogy and geochemistry of basalt weathering, Holes 417A and 418A. In Donnelly, T., Francheteau, J., Bryan, W., Robinson, P., Flower, M., Salisbury, M., et al., Init. Repts. DSDP, 51, 52, 53, Pt. 2: Washington (U.S. Govt. Printing Office), 1201-1218.

Johnson, H. P., and Hall, J. M., 1978. A detailed rock magnetic and opaque mineralogy study of the basalts from the Nazca Plate. Geophys. J. Astron. Soc., 52:45-64.

Lawrence, J. R., Gieskes, J. M., and Broecker, W. S., 1975. Oxygen isotope and cation composition of DSDP pore waters and the alteration of Layer II basalts. Earth Planet. Sci. Lett., 27:1-10.

Lister, C. R. B., 1974. On the penetration of water into hot rock. Geophys. J. R. Astron. Soc., 39:465-509.

Lonsdale, P. F., Bischoff, J. L., Burns, V. M., et al., 1980. A hightemperature hydrothermal deposit on the seabed at a Gulf of California spreading center. Earth Planet. Sci. Lett., 49:8-20. 
Mottl, M. J., and Holland, H. D., 1978. Chemical exchange during hydrothermal alteration of seawater-I. Experimental results for major and minor components of seawater. Geochim. Cosmochim. Acta, 42:1103-1115.

Muehlenbachs, K., 1977. Oxygen isotope geochemistry of DSDP Leg 37 rocks. In Aumento, F., Melson, W. G., et al., Init. Repts. DSDP, 37: Washington (U.S. Govt. Printing Office), 617-619. 1979. The alteration and aging of the basaltic layer of sea floor: Oxygen isotope evidence from DSDP/IPOD Legs 51, 52, and 53. In Donnelly, T., Francheteau, J., Bryan, W., Robinson, P., Flower, M., Salisbury, M., et al., Init. Repts. DSDP, 51, 52, 53, Pt. 2: Washington (U.S. Govt. Printing Office), 1159-1167.

Murdmaa, I. O., and Rozanove, T. V., 1976. Hess Deep bottom sediments. Geological-Geophysical Researches in the Southeastern Part of the Pacific Ocean: Moscow (Nauka), pp. 252-260. (In Russian)

Nathan, Y., 1969. Studies on palygorskite (Ph.D. dissert.]. Hebrew University, Jerusalem.

Natland, J., and Melson, W., 1980. Compositions of basaltic glasses from the East Pacific Rise and Siqueiros fracture Zone, near $9^{\circ} \mathrm{N}$. In Rosendahl, B. R., Hekinian, R., et al., Init. Repts. DSDP, 54: Washington (U.S. Govt. Printing Office), 705-723.

Perry, E. A., Gieskes, J. M., and Lawrence, J. R., 1976. Mg, Ca, and $\mathrm{O}^{18} / \mathrm{O}^{16}$ exchange in the sediment-pore water system, Hole 149 , DSDP. Geochim. Cosmochim. Acta, 40:413-423.

Pimm, A. C., 1973. Trace element determinations compared with $\mathrm{X}$-ray diffraction results of brown clay in the central Pacific. In Winterer, E. L., Ewing, J. I., et al., Init. Repts. DSDP, 17: Washington (U.S. Govt. Printing Office), 511-514.

Pritchard, R. G., 1979. Alteration of basalts from Deep Sea Drilling Project Legs 51, 52, and 53, Holes 417A and 418A. In Donnelly, T., Francheteau, J., Bryan, W., Robinson, P., Flower, M., Salisbury, M., et al., Init. Repts. DSDP, 51, 52, 53, Pt. 2: Washington (U.S. Govt. Printing Office), 1185-1191.

Robinson, P., Flower, M., Schmincke, H.-U., et al., 1977. Low temperature alteration of oceanic basalts, DSDP Leg 37. In Aumento,
F., Melson, W., et al., Init. Repts. DSDP, 37: Washington (U.S. Govt. Printing Office), 775-793.

Scheidegger, K. F., and Stakes, D. S., 1977. Mineralogy, chemistry, and crystallization sequence of clay minerals in altered tholeiitic basalts from the Peru Trench. Earth Planet. Sci. Lett., 36: 413-422.

, 1979. X-ray diffraction and chemical study of secondary minerals from Deep Sea Drilling Project Leg 51 Holes 417A and 417D. In Donnelly, T., Francheteau, J., Bryan, W., Robinson, P., Flower, M., Salisbury, M., et al., Init. Repts. DSDP, 51, 52, 53, Pt. 2: Washington (U.S. Govt. Printing Office), 1253-1263.

Seyfried, W. E., Jr., Shanks, W. C., III, and Dibble, W. E., Jr., 1978. Clay mineral formation in DSDP Leg 34 basalt. Earth Planet. Sci. Lett., 41:265-276.

Siffert, B., and Wey, R., 1962. Synthèse d'une sépiolite à température ordinaire. R. Hebd. Seances Acad. Sci., 254:1460-1463.

Stonecipher, S. A., 1976. Origin, distribution, and diagenesis of phillipsite and clinoptilolite in deep-sea sediments. Chem. Geol., 17: 307-318.

Tomasson, J., and Kristmannsdottir, H., 1972. High-temperature alteration minerals and thermal brines, Reykjanes, Iceland. Contrib. Mineral. Petrol., 36:123-134.

Vallier, T. C., 1974. Volcanogenic sediments and their relation to landmass volcanism and sea floor-continent movements, Western Indian Ocean, Leg 25, Deep Sea Drilling Project. In Simpson, E. S. W., Schlich, R., et al., Init. Repts. DSDP, 25: Washington (U.S. Govt. Printing Office), 513-542.

Warshaw, C. M., and Roy, R., 1961. Classification and a scheme for the identification of layer silicates. Geol. Soc. Am. Bull., 72: $1455-1492$.

Weaver, C. E., and Pollard, L. D., 1973. The Chemistry of Clay Minerals: Amsterdam (Elsevier).

Wolery, T. J., and Sleep, N. H., 1976. Hydrothermal circulation and geochemical flux at mid-ocean ridges. J. Geol., 84:249-275.

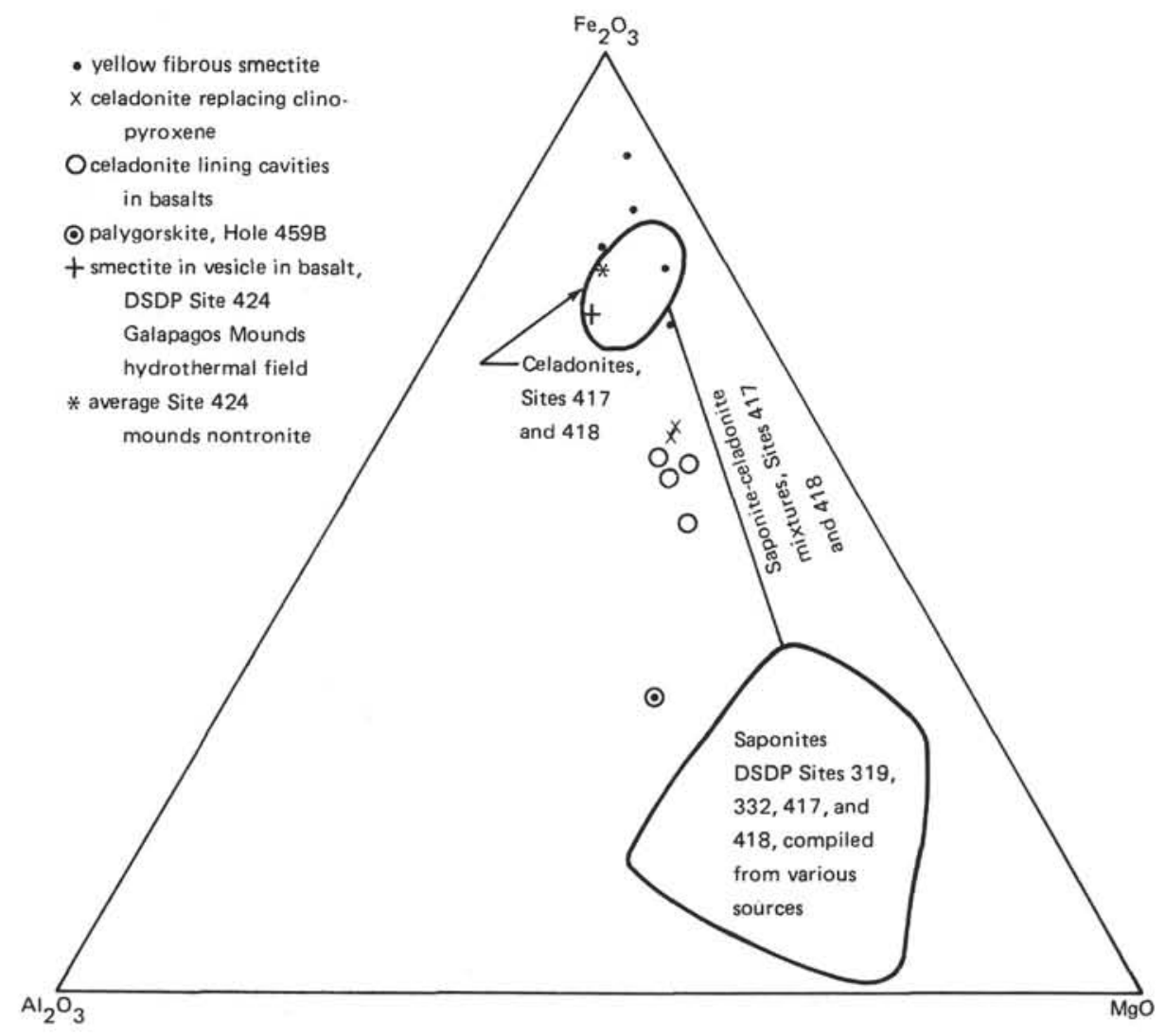

Figure 15. Ternary $\mathrm{Fe}_{2} \mathrm{O}_{3}-\mathrm{Al}_{2} \mathrm{O}_{3}-\mathrm{MgO}$ diagram for clay minerals of Hole 459B. 